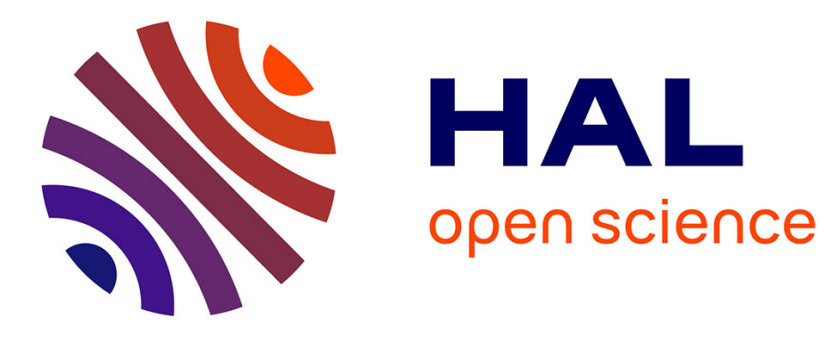

\title{
Edible Polymers for Essential Oils Encapsulation: Application in Food Preservation
}

Francesca Froiio, Ashik Mosaddik, Mahmud Tareq Morshed, Donatella Paolino, Hatem Fessi, Abdelhamid Elaïssari

\section{- To cite this version:}

Francesca Froiio, Ashik Mosaddik, Mahmud Tareq Morshed, Donatella Paolino, Hatem Fessi, et al.. Edible Polymers for Essential Oils Encapsulation: Application in Food Preservation. Industrial and engineering chemistry research, 2019, 58 (46), pp.20932-20945. 10.1021/acs.iecr.9b02418 . hal-02989990

\section{HAL Id: hal-02989990 \\ https://hal.science/hal-02989990}

Submitted on 19 Nov 2020

HAL is a multi-disciplinary open access archive for the deposit and dissemination of scientific research documents, whether they are published or not. The documents may come from teaching and research institutions in France or abroad, or from public or private research centers.
L'archive ouverte pluridisciplinaire HAL, est destinée au dépôt et à la diffusion de documents scientifiques de niveau recherche, publiés ou non, émanant des établissements d'enseignement et de recherche français ou étrangers, des laboratoires publics ou privés. 


\title{
Edible Polymers for Essential Oils Encapsulation: Application in Food Preservation
}

\author{
Francesca Froiio $^{1,5}$, Ashik Mosaddik ${ }^{2,3}$, Mahmud Tareq Morshed ${ }^{4}$, Donatella Paolino ${ }^{5}$, Hatem \\ Fessi $^{1}$, Abdelhamid Elaissari*1
}

${ }^{1}$ Univ Lyon, University Claude Bernard Lyon-1, CNRS, LAGEP-UMR 5007, F-69622 Lyon, France.

${ }^{2}$ Clinical Pharmacy Department, Institute for Research \& Medical Consultations, Imam

Abdulrahman Bin Faisal University, Dammam 31441, Saudi Arabia.

${ }^{3}$ Pharmacy Department, Rajshahi University, Rajshahi 6205, Bangladesh

${ }^{4}$ Department of Molecular Sciences, Macquarie University, NSW 2109, Australia.

${ }^{5}$ Department of Experimental and Clinical Medicine, University "Magna Gracia" of Catanzaro, Campus Universitario “S. Venuta”, Viale S. Venuta, I-88100, Catanzaro, Italy.

Corresponding author : abdelhamid.elaissari@univ-lyon1.fr

\section{ABSTRACT}

According to the World Health Organization, every year 2 billion people worldwide get sick because of unsafe food. For this reason, food preservation from fungi, bacteria and other contaminants, is important to ensure the safety and quality of food to the consumers.

Now a day, there is an increasing demand for natural preservatives which are safe in the food industry. Among these natural compounds with antimicrobial activity, essential oils have aroused 
considerable interest in the food industry. Unfortunately, essential oils have numerous limitations in their use, mainly due to their hydrophobic property, which need to be encapsulated before use. The main goal of this specific review is to focus on the encapsulation of essential oils using edible polymers.

Keywords: Food preservation; antimicrobials; essential oils; encapsulation; edible polymers.

\section{INTRODUCTION}

The U.S. Food and Drug Administration define food antimicrobials agent as added 'chemical compounds to foods or food packaging able to inhibit activity of bacteria and also to reduce growing process of spoilage microorganisms'. ${ }^{1}$

The need to preserve food has been felt since ancient times by using simple and inexpensive methods such as drying (of salty meat and fish), smoking process generally used for fishes and sugar based conservation process (adapted to fruits) but these methods are inefficient to completely protect foods from degradation. During storage, transport and post-harvest processing, microbial contamination such as viruses, fungi, bacteria, moulds, mycotoxin and yeasts cause a loss of quantity and quality of food products.

For this reason, chemicals preservatives were introduced in order to avoid food contamination and spoilage caused by different microorganisms but most of these compounds have shown toxic effects on human health and the environment leading to an increase in the demand for natural origin preservatives. In recent years, food industry developed a great interest in research on antimicrobial compounds, which guarantee food safety and microbiological quality and allows extending the shelf life of food products. Particular attention has been placed to natural antimicrobials but these compounds lose their properties during the processing and conservation phases. In order to solve these problems different strategies have been studied; in particular microencapsulation technique 
represents a good strategy to protect antimicrobials compounds..$^{2}$ In recent past, Essential Oils (EOs) and their major bioactive compounds have been widely studied to be use as food preservatives alternative to synthetic ones..$^{3,45}$ The main advantage of using essential oils in the presence of additional chemical compounds is the possible synergistic effect, which may induces long time preservation. ${ }^{6}$

The antimicrobial effectiveness of numerous essential oils has been evaluated by Alboofetileh et al. (2014). The used essential oils are clove, coriander, cumin, cinnamon, marjoram, and caraway and evaluated against E. coli, S. aureus, and L. monocytogenes pathogens. The study consists also examining the effect of encapsulating three essential oils in chitosan/clay films on some pathogens. The antibacterial activity was found to be more marked for clove, cinnamon, coriander, cumin, and caraway. Interestingly, the antibacterial activity was preserved when the essential oils are incorporated in the films and influences by the incorporated essential oil nature and amount.

In addition, it was reported that the films containing essential oils were more active against the Gram-positive bacteria ( $S$. aureus and L. monocytogenes) than the Gram-negative organism (E. coli).

For the highest concentration of marjoram essential oil, a complete inhibition of growth was observed which confirms the antimicrobial activity of the essential oil and validates its increase in stability once incorporated in the films. ${ }^{7}$ Chitosan and carob gum polymeric matrices were previously used with different Citrus essential oils, and their inhibition potential against Aspergillus Flavus (Trichocomaceae) was evaluated with in vitro and in artificially infected fruits as reported by Aloui et al. (2014). In addition, to ensure the lack of unusual odors and flavors, the effect of the treatment on the sensorial characteristics of the fruits was studied. Results showed that both bergamot and orange essential oils significantly reduce spore germination at $2 \%(\mathrm{v} / \mathrm{v})$ concentration. Reductions of $87 \%$ and $90 \%$ were obtained for bergamot and orange oil respectively. However, bergamot oil was more effective in reducing bacterial growth comparing to orange oil. Citrus essential oils, rich in limonene, sabinene, linalool, octanal, myrcene, and other compounds, 
when coated with chitosan based formulations, showed a reduction of fungal degradation of infected fruits by $52 \%$ - $62 \%$ after 12 days. Plus, undesirable flavors or odors were not detected in fruits. These results indicate that combining essential oils with polymeric matrices can be a promising technique for the production of antifungals designed to control the post-harvest growth of A. flavus. $^{8}$ In another study, films based on the mucilage of quince seeds loaded with thyme essential oil at a concentration of up to $2 \%$ were prepared. Physical properties, mechanical properties, barrier properties, antibacterial activity, and antioxidant activity were evaluated. 11 species of food-related bacterial were used for the antimicrobial activity study using agar disc diffusion method. It was found that all studied bacteria are sensitive to the formulation at $1 \%$ essential oil concentration. Plus, the strongest inhibitory effect was observed against Shewanella putrefaciens (Shewanellaceae), L. monocytogenes(Listeriaceae), and S. aureus (Staphylococcaceae). Additionally, the antioxidant activity increased when adding the thyme essential oil to the quince seed mucilage, and the glass transition decreased. The formed structure were studied by scanning electron microscopy. ${ }^{9}$ These formulations offer a new strategy for the protection of food products against degradation following harvesting.

\section{ANTIMICROBIAL COMPOUNDS USED AS FOOD PRESERVATIVES}

Numerous chemical compounds have been used in the past as food preservatives, such as benzoic acid and p-hydroxybenzoic acid, propionic acid, nitrites, sulfites, butylated hydroxyanisole (BHA) and butylated hydroxytoluene (BHT) (see Table 1 in supporting information). Preservatives have revolutionized eating habits. ${ }^{10}$ They are subdivided according to their mechanism of action in antimicrobials, antioxidant and antibrowning. ${ }^{11}$

Preservatives are accepted if they do not compromise the health of consumers (Council Directive 89/107/EEC). Their possible toxic effects on the organism depends on the dose, route of administration and their chemical form..$^{32}$ On the other hand, legislation reduced the use and the 
doses of chemical ingredients in food and beverage. ${ }^{33}$ Despite their effectiveness in food preservation, there are many doubts about their safety on human health; in fact, they can interact with nutrient altering their absorption, transport, metabolism and elimination.

For example, nitrate and nitrite are largely used for "curing" meat; they inhibit anaerobic bacteria, such as Clostridium botulinum ${ }^{34}$ nitrite is also responsible of the bright pink colour and of a good flavour of meat. Nitrate can be reduced to nitrite by microorganisms present in raw meat or in oral cavity; it inhibits the growth of some microorganisms. Nitrites are converted into nitrosamines, in the acidic environment of the stomach: nitrosamines could be carcinogenic. ${ }^{22}$ Several studies have shown that nitrite is dangerous for human health: nitrite in fact, can cause methemoglinemia, by oxidation of oxyhemoglobin to ferrihemoglobin. ${ }^{20,35}$ High consumption of nitrates and derivatives and a possible increase of the risk of gastric cancer has been hypothesized in different studies but more in-depth studies are necessary to establish a secure correlation. ${ }^{21,36} \mathrm{~A}$ correlation between a high consumption of red meat and a significantly increased risk of development of colorectal cancer has been shown in numerous studies (World Cancer Research Fund [WCRF] 2007). ${ }^{37}$

\section{ESSENTIAL OILS WITH ANTIMICROBIAL PROPERTIES}

In the last few years, there has been an increase in consumers' rejection of synthetic preservatives; this caused the need to find natural antimicrobials for food preservation. Among natural compound Essential oils have aroused particular attention in researchers for their widely documented antimicrobial activity. ${ }^{38,39}$ Essential oils (EOs) are natural, aromatic, oily, liquids and volatile compounds obtained from different parts of the plant (flowers, buds, seeds, leaves, twigs, bark, herbs, wood, fruits and roots). ${ }^{3}$ They possess antibacterial ${ }^{40}$, antifungal ${ }^{41}$ and antiviral ${ }^{42}$ activity. $^{2}$ There is a big demand of essentials oils from food industry; in fact, due to their antimicrobial activities even against multi-resistant bacteria, they are used for food preservation. ${ }^{3}$ In the table 2 (see supporting information) are listed different essential oils with antimicrobial activity. 


\section{$\underline{3.1 \text { Chemical composition }}$}

Essential oils have very complex chemical composition. They contain volatile compounds in different percentages divided into four categories based on their chemical structure: terpenes, terpenoids, phenylpropenes and "others". Terpens are organic compounds constituted by several isoprene units $\left(\mathrm{C}_{5} \mathrm{H}_{8}\right)$. They have cyclic structures constituted by hydrocarbon backbone. They are classified in monoterpenes $\left(\mathrm{C}_{10} \mathrm{H}_{16}\right)$, sesquiterpenes $\left(\mathrm{C}_{15} \mathrm{H}_{24}\right)$ and diterpenes $\left(\mathrm{C}_{20} \mathrm{H}_{32}\right)$ based on the number of carbon atoms. Terpenoids are obtained by the enzymatic modification of terpenes into alcohols, esters, aldehydes, ketones, ethers, phenols and epoxides.

Monoterpenoids and sesquiterpenoids are the most abundant terpenes present in essential oils. Phenylpropenes consist of an aromatic phenol group with six carbon atoms and three-carbon propene tail of cinnamic acid. Phenilpropenes and terpenoids are the EOs component with the greatest antimicrobial activity. ${ }^{64}$ Cosentino et al. (1999), established that phenolic components are the main responsible for the antibacterial activity of EOs. ${ }^{65}$ Moreover, antimicrobials activity depends on the substituents on the aromatic ring. Finally, EOs contain a series of degradation components such as allicin and allyl isothiocyanate. ${ }^{64}$ The amount of single component of EOs and their chemical composition are responsible for their antimicrobial activity. ${ }^{66}$ It is important to highlight that harvesting seasons and geographical source influence the chemical composition of a particular plant species..$^{51,67}$

Gas chromatography/mass-spectrometry analysis is used in order to determine the composition of the EOs.$^{50}$ EOs are extracted from plant raw component by different method that can be classified into conventional methods and innovative methods. Conventional methods are based on water distillation by heating, include hydrodistillation, entrainment by water steam, organic solvent extraction and cold pressing; the main limitation for their use is the thermo-lability of EOs. Conversely, the innovative methods are faster and less expansive such as: supercritical fluid extraction (SCFE), subcritical extraction liquids $\left(\mathrm{H}_{2}\right.$ and $\left.\mathrm{CO}_{2}\right)$, extraction with subcritical $\mathrm{CO}_{2}$, microwave extraction process and the instant controlled pressure drop. ${ }^{68}$ Another important feature 
of the EOs to be taken into consideration is the possibility that there are interactions between their various chemical components because they are complex mixtures of numerous molecules. For these reasons, it is necessary to keep in mind that the antimicrobial effect of essential oils may be due to the component present in greater quantity or to a possible interaction between different molecules. ${ }^{66}$

\subsection{Possible antimicrobial mechanisms}

EOs mechanism of action has not yet been clarified but seems to be due to their hydrophobic nature ${ }^{69}$ Due to the large number of different chemical compounds is more difficult to describe the exact mechanism of antimicrobial action. A possible mechanism of antibacterial action is schematized in figure 1. Due to their hydrophobic nature, EOs component can interact with the lipids of the bacterial cell membrane and mitochondria, altering the normal bacterial structure by increasing the membrane permeability and causing loss of cellular content. ${ }^{3,70}$ Furthermore, there is a reduction of the cytoplasmic $\mathrm{pH}$, a decrease of the ATP synthesis and a change in membrane potential. All these events cause bacterial death. ${ }^{69}$

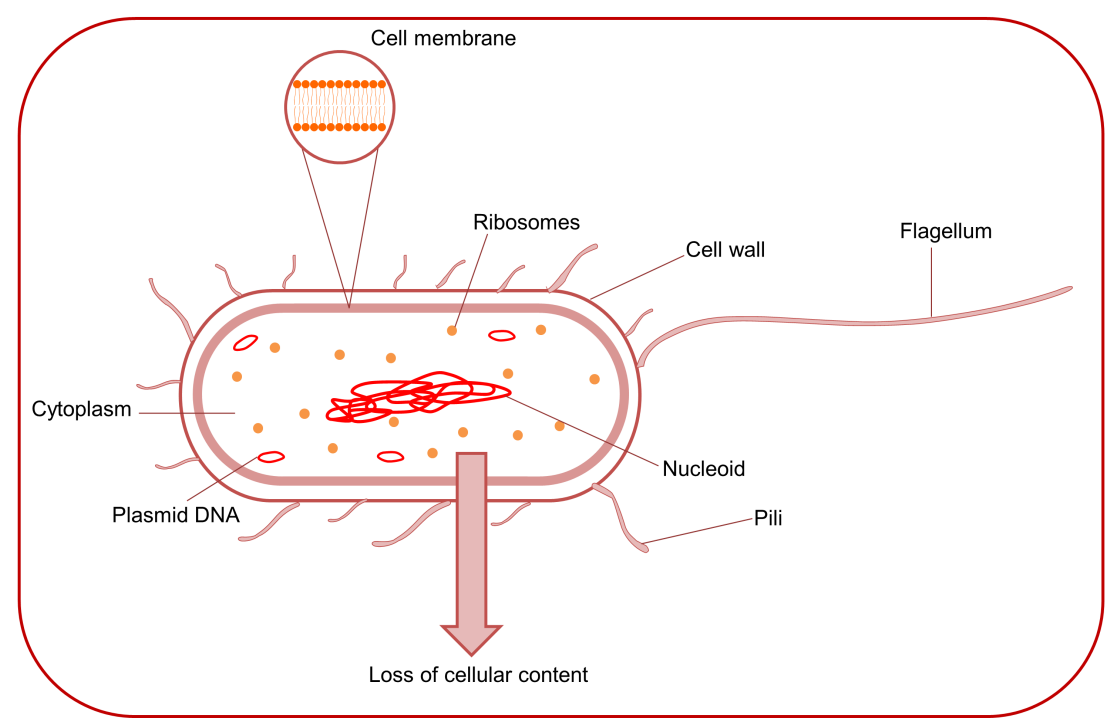

Figure 1. Representation of essential oils mechanism of action. The arrow in the figure indicates the loss of cellular content caused by the possible interaction of the EOs components with the cell membrane. 
The antimicrobial tests currently available on the market, used to study the antimicrobial activity of essential oils, are hydrophilic due to the hydrophilic nature of the culture broth (for example, RPMI and Mueller-Hinton broth) $)^{71,72}$ while essential oils are hydrophobic. For this reason, surfactants, such as tween 80 , are used to mix a hydrophilic phase with essential oils. ${ }^{71}$ Tween 80 and other surfactants, could themselves cause a decrease in bacterial growth affecting the results obtained from the antimicrobial activity due to the studied essential oil. There is therefore a need to produce and market new tests to study the in vitro antimicrobial activity of essential oils and other lipophilic compounds.

\subsection{Limitation in the use of essential oils as food preservatives}

The U.S. Code of Federal Regulations and FDA classified several specific chemical active molecules of essential oils such as linalool, thymol, eugenol, carvone, cinnamaldehyde, vanillin, carvacrol, citral, and limonene as generally recognized as safe (GRAS). Clove, oregano, thyme, nutmeg, basil, mustard, and cinnamon are among EOs considered as GRAS. ${ }^{73}$

Despite their documented antimicrobial power, the use of essential oils in food preservation presents numerous obstacles such:

i) Hydrophobic component of essential oils can interact with food components such as fat, starch and proteins. ${ }^{64}$

ii) The high quantity of essential oils to be used to have an antimicrobial effect can alter the taste of food.$^{74}$

iii) EOs are volatile, photosensitive and temperature sensitive and moreover high temperatures, UV light and oxidation compromise their biological activity.$^{68}$

iv) The dose necessary to obtain antimicrobial effects could induce toxicity. ${ }^{75}$

These problems represent a limitation in their use, therefore it is necessary to find solutions that can allow the use of EOs in order to have maximum effectiveness and safety. 


\section{ENCAPSULATION OF ESSENTIAL OILS}

Encapsulation techniques of essentials oils represent an excellent strategy to overcome the problems related to their use. Encapsulation technique offers many advantages:

1) Protecting EOs from degradation;

2) Encapsulation of hydrophobic EOs into hydrophilic polymers makes them soluble in a watery environment;

3) Masking the strong aroma of EOs that could negatively alter the taste of food. ${ }^{76}$

4) Avoiding the interactions with food components. ${ }^{77}$

5) Targeting antimicrobials compounds where microorganisms are preferentially located with consequent increasing of their bioactivity and reducing the amount necessary to achieve the antimicrobial effect..$^{77}$

Different encapsulation techniques were used for delivery of EOs used as preservatives in food. In the table 3 (see supporting information) are listed the main technique used in food preservation.

Recently, two new techniques for the encapsulation of essential oils to be used in food preservation have been developed. They are randomly methylated beta cyclodxtrins (RAMEB) and Pickering emulsions.

In a recent work, Kfoury et al. (2014), prepared a complex of native cyclodextrins ( $\alpha-, \beta-, \gamma-$ cyclodextrin) and randomly methylated-cyclodextrin (RAMEB) with the main compounds of basil and terragon essential oils. They obtained a stable system to improve the use of essential oils in food preservation. ${ }^{90}$ Zhou et al prepared and characterized oregano essential oils Pickering emulsion stabilized using cellulose nanocrystals to study their antimicrobial activity on bacteria responsible for food contamination. Although the emulsions antimicrobial activity was slightly less effective compared with pure essential oil; the obtained results encourage further research to improve this type of emulsions in order to use them in food preservation. ${ }^{91}$ 
It has been shown that nano-encapsulation is more effective than microencapsulation because the smaller nanosystems, compare with microcapsules, are more stable and more compatible with food matrix.$^{85}$ In fact, microparticles represent good systems for protecting essential oils but not for increasing antimicrobial activity while nanosized particles are able to increase the passive cellular absorption mechanisms with a consequent greater antimicrobial activity. ${ }^{75}$ Furthermore, unlike microparticles, nanoparticles allow active targeting of the bacterial surface.$^{85}$ Essential oils have also been encapsulated in Solid Lipid Nanoparticles ${ }^{90}$ but these nanosystems have not been applied in food-preservation field.

Table 4 (see supporting information) contains examples of different particles loaded with essential oils, which have different applications, not just antimicrobial.

\section{EDIBLE POLYMER USED FOR FOOD ENCAPSULATION}

Edible polymers can be defined as safety, biodegradable and biocompatible materials that can be consumed. They are obtained from renewable, edible ingredients and their functionality depends on their barrier, mechanical, and colour properties. The edible polymer are used as carriers for compounds with antimicrobial and antioxidant activity and for the production of films and coatings. ${ }^{128}$

The choice of the material to be used as coating or carrier for the encapsulation of EOs is crucial; in fact the polymer must protect the oil, guarantee its controlled release, be water-soluble, biocompatible and biodegradable and have a low cost. ${ }^{129}$

Edible polymers are safe for human health and they can be consumed with foods. Edible polymers can preserve the nutritional and sensory characteristics of food, its safety and freshness during storage. They are an alternative to synthetic polymers and plastic materials, thus representing advantages both at the environmental level and for human health. The interest of the food industry 
towards edible polymers is constantly increasing mainly due to the continued demand for safe and high-quality food by consumers. ${ }^{128}$

They can be produced from proteins, polysaccharides and lipids. There are four categories of compounds used to obtain edible polymers: hydrocolloids (proteins and polysaccharides), polypeptides, lipids, and composites. ${ }^{128}$ The main edible polymers used in the food industry are listed in table 5 (see supporting information).

Gómez-Estaca et al. (2010) found a strong antimicrobial activity of gelatin-chitosan-based films in which clove essential oil was loaded. The clove-loaded edible films caused inhibition of six studied microorganisms such as Escherichia coli and Listeria innocua..$^{53}$

In another research study $\mathrm{Wu}$ et al. (2012) prepared zein-based edible nanoparticles in which thymol and carvacrol essential oils were encapsulated: the obtained nanoparticles effectively reduce Escherichia coli growth. The obtained results demonstrated how essential oils nanoencapsulation allows their use in food preservation. ${ }^{80}$

\section{REGULATORY ASPECT}

Actually, there is no established accepted worldwide regulatory plan for nanotechnologies. The safety of nanotechnological products is a fundamental requirement for applications in the food industry. For this reason, in 2012, European Union established that all food ingredients obtained from nanotechnological processes must be approved before being put on the market has been drafted in 2012. The U.S. FDA has developed guidelines on the use of nanomaterials for food application while a list of nanofoods and beverages marketed in Europe is available from 2012. ${ }^{149}$

The European Food Safety Authority (EFSA) contributes to EU food surveillance by publishing documents related to the safe application of nanotechnologies in food field. EFSA, in 2011, issued a document about the risks arising from the use of nanotechnologies in the food and feed sectors. Furthermore, in 2012, EFSA provided a Nanonetwork to create an easy way of communication with 
EU Member states. The purpose of Nanonetwork is to facilitate the exchange of information concerning the safety of the use of nanotechnologies in food field. EU legislation established that all the nanomaterials contained in food products must be specifically indicated in the final label of the product in order to inform consumers. ${ }^{150}$

Nanotechnology provides the opportunity to use essential oils as natural food preservatives protecting them from degradation and increasing their effectiveness.

In any case, further studies are needed to understand the possible toxicological effects of nanomaterials before their application as delivery of natural compounds in food preservation. ${ }^{71}$

\section{FUTURE DIRECTION}

The use of essential oils in combination with emergent technologies, such as high isostatic pressures (HIP), thermal treatments, pulsed electric field and actively sensitive packaging against foodborne pathogens has also been described. ${ }^{151}$ For instance, Espina and co-workers (2011) demonstrated that combined treatments of low concentrations of orange, lemon and mandarin EOs with a mild heat treatment have a strong synergistic antibacterial activity. ${ }^{152}$

Application of nanotechnology to the development of edible coatings includes various nanosystem such as nanoemulsions, polymeric nanoparticles, nanofibers, solid lipid nanoparticles, nanostructured lipid carriers, nanotubes, nanocrystals, or mixtures of organic and inorganic nanosized components. Several studies of the encapsulation of antimicrobial essential oils into these nanosystem have been documented, however utilization of these system as edible coating has not been fully explored. ${ }^{153,154}$ Out of these nanosystem, nanotube and nanofiber are novel technology for development of edible coating and could be another promising alternative for preservation of foods. Control release packaging (CRP) technology could be another alternative way to deliver the antimicrobial essential oils from active packaging material. CRP uses package to deliver the 
antimicrobials to food product, in a controlled manner, in order to extend the quality and shelf-life and protect food from deterioration. ${ }^{155}$ This innovative technology is relatively new and intensive research needs to be carried out to fill the knowledge gap. However the use of volatile antimicrobials for CRP systems, has been widely reported. ${ }^{156,157,158}$

\section{CONCLUSION}

The spoilage and poisoning of foods by microorganisms is a worldwide problem, which has not yet been completely solved. An appropriate solution for food storage would be beneficial both from an economic point of view and for human health. Natural Essential oils could represent the revolution of food industry because they could completely replace chemical preservatives, obtaining an excellent consent from consumers. The limitation in their use depend on their instability and their unpleasant alteration of the taste of food. Encapsulation of essential oils could be a solution to all these problems. For this reason, it is necessary to find a good method for the EOs encapsulation using suitable edible polymers, safe for human health, which allows the protection of EOs and increase their antimicrobial activity. An innovative EOs delivery system with these characteristics could represent the revolution for food preservation.

\section{Acknowledgments}

The authors are very grateful to Betty P. Udongo for her revision of the language of this manuscript.

\section{REFERENCES}


(1) Davidson, P. M.; Sofos, J. N.; Branen, A. L. Antimicrobials in Food. Boca Raton, FL. CRC Press. 2005.

(2) Castro-Rosas J.; Ferreira-Grosso C.R.; Gómez-Aldapa C.A.; Rangel-Vargas E.; RodríguezMarín M.L.; Araceli Guzmán-Ortiz F.; Falfan-Cortes R.N. Recent advances in microencapsulation of natural sources of antimicrobial compounds used in food - A review. Food Res. Int. 2017, 102, 575-587.

(3) Burt, S. Essential oils: their antibacterial properties and potential applications in foods-a review. Int. J. Food Microbiol. 2004, 94, 223-253.

(4) Bluma, R.; Amaiden, M. R.; Daghero, J.; Etcheverry, M. Control of Aspergillus section Flavi growth and aflatoxin accumulation by plant essential oils. J. Appl. Microbiol. 2008, 105, 203-214.

(5) Ahmadi, F.; Sadeghi, S.; Modarresi, M.; Abiri, R.; Mikaeli, A. Chemical composition, in vitro anti-microbial, antifungal and antioxidant activities of the essential oil and methanolic extract of Hymenocrater longiflorus Benth., of Iran. Food Chem. Toxicol. 2010, 48, 11371144.

(6) Jiang, Z.; Akhtar, Y.; Bradbury, R.; Zhang, X.; Isman, M.B. Comparative Toxicity of Essential Oils of Litsea pungens and Litsea cubeba and Blends of Their Major Constituents against the Cabbage Looper, Trichoplusiani. J. Agric. Food Chem. 2009, 57 (11), 48334837.

(7) Alboofetileh, M.; Rezaei, M.; Hosseini, H.; Abdollahi, M. Antimicrobial activity of alginate/clay nanocomposite films enriched with essential oils against three common foodborne pathogens. Food Control 2014, 36(1), 17.

(8) Aloui, H.; Khwaldia, K.; Licciardello, F., Mazzaglia, A.; Muratore, G.; Hamdi, M.; Restuccia, C. Efficacy of the combined application of chitosan and Locust Bean Gum with different citrus essential oils to control postharvest spoilage caused by Aspergillus flavus in dates. Int. J. Food Microbiol. 2014, 170, 2-18.

(9) Jouki, M.; Mortazavi, S. A.; Yazdi, F. T.; Koocheki, A. Characterization of antioxidantantibacterial quince seed mucilage films containing thyme essential oil. Carbohydr. Polym. 2014, 99, 537-546.

(10) Parke D.V.; Lewis D.F.V. Safety aspects of food preservatives, Food Addit. Contam. 1992, 9, 561-577.

(11) Carocho, M.; Barreiro, M.F.; Morales, P.; Ferreira, I.C.F.R. Adding molecules to Food, Pros a Cons: A review of synthetic and natural food additives. Compr. Rev. Food Sci. Food Saf. 2014, 13, 377-399.

(12) Maier, E.; Kurz, K.; Jenny, M.; Schennach, H.; Ueberall, F.; Fuchs, D. Food preservatives sodium benzoate and propionic acid and colorant curcumin suppress Th1-type immune response in vitro. Food Chem. Toxicol. 2010, 48, 1950-1956.

(13) Binstok, G.; Campos, C.; Varela, O.; Gerschenson, L.N. Sorbate-nitrite reactions in meat products. Food Res. Int . 1998, 31, 581-585.

(14) Mamur, S.; Yuzbasioglu, D.; Unal, F.; Yilmaz, S. Does potassium sorbate induce genotoxic or mutagenic effects in lymphocytes? Toxicol. In Vitro 2010, 24, 790-794.

(15) Farag, R.S.; Daw, Z.Y.; Hewedi, F.M.; El-Baroty, G.S.A. Antimicrobial activity of some Egyptian spice essential oils. J. Food Prot. 1989, 52 (9), 665-667.

(16) Michilis, A.; Vandemonten, G.; Duchateau, J.; Yernault, J.C. Anaphylaxis with sodium benzoate. The Lancet, 1991, 337, 1424-1425.

(17) Zengin, N.; Yuzbasioglu, D.; Unal, F.; Yilmaz, S.; Aksoy, H. The evaluation of the genotoxicity of two food preservatives: sodium benzoate and potassium benzoate. Food Chem. Toxicol. 2011, 49, 763-769.

(18) Routledge, E.J.; Parker, J.; Odum, J.; Ashby, J.; Sumpter, J.P. Some alkyl hydroxy benzoate preservatives (parabens) are estrogenic. Toxicol. Appl. Pharmacol. 1998, 153, 12-19. 
(19) Oishi, S. Effects of propyl paraben on the male reproductive system. Food Chem. Toxicol. 2002, 40-12, 1807-1813.

(20) Fan, A.M.; Steinberg V.E. Health implications of nitrate and nitrite in drinking water: an update on methemoglobinemia occurrence and reproductive and developmental toxicity. Regul. Toxicol. Pharmacol. 1996, 23, 35-43.

(21) Song, P.; Wu, L.; Guan, W. Dietary nitrates, Nutrients 2015, 7, 9872-9895.

(22) Honikel K.O. The use and control of nitrate and nitrite for the processing of meat products. Meat Sci. 2008, 78, 68-76..

(23) Türkoğlu, Ş. Evaluation of genotoxic effects of sodium sulphite, potassium sulphite and calcium sulphite on the root meristem cells of Allium cepa. Fresen. Environ Bull 2009, 18, 804-810.

(24) Meng, Z.; Qin, G.; Zhang, B.; Bai, J. DNA damaging effects of sulfur dioxide derivatives in cells from various organs of mice. Mutagenesis 2004, 19, 465-468.

(25) Son, S.M.; Moon, K.D.; Lee, C.Y. Inhibitory effects of various antibrowning agents on apple slices. Food Chem. 2001, 73, 23-30.

(26) McEvily, A. J.; Iyengar, R.; Orwell, W. S. Inhibition of enzymatic browning in foods and bever ages. CRC Crit. Rev. Food Sci. Nutr. 1992, 32, 253-273.

(27) Sasaki, Y.F.; Kawaguchi, S.; Kamaya, A.; Ohshita, M.; Kabasawa, K.; Iwama, K.; Taniguchi, K.; Tsuda, S. The comet assay with 8 mouse organs: results with 39 currently used food additives. Mutat. Res. 2002, 519, 103-119.

(28) Hirose, M.; Hoshiya, T.; Mizoguchi, Y.; Nakamura, A.; Akagi, K.; Shirai, T. Green tea catechins enhance tumor development in the colon without effects in the lung or thyroid after pretreatment with 1,2-dimethylhydrazine or 2,20 -dihydroxy-di-n-propylnitrosamine in male F344 rats. Cancer Lett. 2001, 168, 23-9.

(29) Dolatabadi, J. E. N.; Kashanian, S. A review on DNA interaction with synthetic phenolic food additives. Food Res. Int. 2010 43, 1223-1230.

(30) Yılmaz, S.; Ünal, F.; Yüzbaşığlu, D.; Aksoy, H. Clastogenic effects of food additive citric acid in human peripheral lymphocytes. Cytotechnology 2008. 56, 137-140.

(31) Lan, W.C.; Lan W.H.; Chan, C.P.; Hsieh, C.C.; Chang, M.C.; Jeng, J.H. The effects of extracellular citric acid acidosis on the viability, cellular adhesion capacity and protein synthesis of cultured human gingival fibroblasts. Aust. Dent. J. 1999, 44 (2), 123-130.

(32) Quattrucci, E.; Masci, V. Nutritional aspects of food preservatives. Food Addit. Contam. 1992, 9, 515-525.

(33) Brul, S.; Coote, P. Preservative agents in foods: Mode of action and microbial resistance mechanisms. Int. J. Food Microbiol. 1999, 50,1-17.

(34) Sebranek J.G.; Bacus J.N. Meat products without direct addition of nitrate or nitrite: what are the issues? Meat Sci. 2007, 77, 136-147.

(35) Cammack, R.; Joannou, C.L.; Cui, X.Y.; Torres Martinez, C.; Maraj, S.R.; Hughes, M.N. Nitrite and nitrosyl compounds in food preservation. Biochim. Biophys. Acta 1999, 1411, 475-488.

(36) Miller, P.E.; Lazarus, P.; Lesko, S.M.; Cross, A.J.; Sinha, R.; Laio, J.; Zhu, J.; Harper, G.; Muscat, J.E.; Hartmen T.J. Meat related compounds and colorectal cancer risk by anatomical subsite. Nutr. Cancer 2013, 65, 202-226.

(37) [WCRF] World Cancer Research Fund/American Institute for Cancer Research, 2007. Food, nutrition and the prevention of cancer: a global perspective. Washington (DC): World Cancer Research Fund/American Institute for Cancer Research; 2007. p. 517, http://eurlex.europa.eu/legal-content/EN/TXT/?uri=LEGISSUM\%3Al21067.

(38) Mayaud, L.; Carricajo, A.; Zhiri, A.; Aubert, G. Comparison of bacteriostatic and bactericidal activity of 13 essential oils against strains with varying sensitivity to antibiotics. Lett. Appl. Microbiol. 2008, 47, 167-173. 
(39) Prabuseenivasan, S.; Jayakumar, M.; Ignacimuthu, S. In vitro antibacterial activity of some plant essential oils. BMC Complement. Altern. Med. 2006, 6, 39.

(40) Oussalah, M.; Caillet, S.; Saucier.; Lacroix, M. Inhibitory effects of selected plant essential oils on the growth of our pathogenic bacteria: E. coli O157:H7, Salmonella typhimurium, Staphylococcus aureus and Listeria monocytogenes. Food Control 2007, 18, 414-420.

(41) Silva, F.; Ferreira, S.; Duarte, A.; Mendonça, D.I.; Domingues, F. C. Antifungal activity of Coriandrum sativum essential oil, its mode of action against Candida species and potential synergism with amphotericin B. Phytomedicine 2011, 19, 42-47.

(42) Reichling, J.; Astani, A.; Schnitzler, P. Screening for antiviral activities of isolated compounds from essential oils. Evid. Based Complement. Alternat. Med. 2011, 2011, 1-8.

(43) Ceylan, E.; Fung, D. Y. C. Antimicrobial activity of spices. J. Rapid Methods Autom. Microbiol. 2004, 12(1), 1-55.

(44) Rojas-Grau, M. A.; Avena-Bustillos, R. J.; Olsen, C.; Friedman, M.; Henika, P. R.; MartinBelloso, O.; Pan, Z.; Mc Hugh T.H. Effects of plant essential oils and oil compounds on mechanical, Barrier and antimicrobial properties of alginate - Apple puree edible films. $J$. Food Eng. 2007, 81(3), 634-641.

(45) Velluti, A.; Sanchis, V.; Ramos, A.J.; Egido, J.; Marin, S. Inhibitory effect of cinnamon, clove, lemongrass, oregano and palmarose essential oils on growth and fumonisin B1 production by Fusarium proliferatum in maize grain. Int. J. Food Microbiol. 2003, 89, 145154.

(46) Velluti, A.; Sanchis, V.; Ramos, A.J.; Turon, C.; Marin, S. Impact of essential oils on growth rate, zearalenone and deoxynivalenol production by Fusarium graminearum under different temperature and water activity conditions in maize grain. J. Appl. Microbiol. 2004, 96, 716-724.

(47) Tajkarimi M.M.; Ibrahim S.A.; Cliver D.O. Antimicrobial herb and spice compounds in food. Food Control 2010, 21, 1199-1218.

(48) Okoh, O. O.; Sadimenko, A. P.; Afolayan, A. J. Comparative evaluation of the antibacterial activities of the essential oils of Rosmarinus officinalis L. obtained by hydrodistillation and solvent free microwave extraction methods. Food Chem. 2010, 120(1), 308-312.

(49) Biondi, D.; Cianci, P.; Geraci, C.; Ruberto, G. Antimicrobial activity and chemical composition of essential oils from sicilian aromatic plants. Flavour Fragr. J. 1993, 8, 331337.

(50) Elgayyar, M.; Draughon, F.A.; Golden, D.A.; Mount, J.R. Antimicrobial Activity of Essential Oils from Plants against Selected Pathogenic and Saprophytic Microorganisms. J. Food Prot. 2001, 64, 7, 1019-1024.

(51) Marino, M.; Bersani, C.; Comi, G. Antimicrobial activity of the essential oils of Thymus vulgaris L. measured using a bioimpedometric method. J. Food Protect. 1999, 62 (9), 10171023.

(52) Smith-Palmer, A.; Stewart, J.; Fyfe, L. Antimicrobial properties of plant essential oils and essences against five important food-borne pathogens. Lett. Appl. Microbiol. 1998, 26, 118 122.

(53) Gómez-Estaca, J.; López de Lacey, A.; López-Caballero, M.E.; Gómez-Guillén, M.C.; Montero, P. Biodegradable gelatin-chitosan films incorporated with essential oils as antimicrobial agents for fish preservation. Food Microbiol. 2010, 27, 889-896.

(54) Juven, B.J.; Kanner, J.; Schved, F.; Weisslowicz, H. Factors that interact with the antibacterial action of thyme essential oil and its active constituents. J. Appl. Bacteriol. 1994, 76, 626-631.

(55) Negi, P. S.; Jayaprakasha, G. K.; Jagan Mohan Rao, L.; Sakariah, K. K. Antibacterial activity of turmeric oil: a byproduct from curcumin manufacture. J. Agric. Food Chem. 1999, 47(10). 4297-4300. 
(56) Bassole, I.H.N.; Ouattara, A.S.; Nebie, R.; Ouattara, C.A.T.; Kabore, Z.I.; Traore, S.A. Chemical composition and antibacterial activities of the essential oils of Lippia chevalieri and Lippia multiflora from Burkina Faso. Phytochemistry 2003, 62, 209-212.

(57) Lachowicz, K. J.; Jones, G. P.; Briggs, D. R.; Bienvenu, F. E.; Wan, J.; Wilcock, A.; Coventry, M. J. The synergistic preservative effects of essential oil of sweet basil (Ocimum basilicum L.) against acid-tolerant food microflora. Lett. Appl. Microbiol. 1998, 26, 209-214.

(58) Ela, M. A.; El-Shaer, N. S.; Ghanem N. B. Antimicrobial evaluation and chromatographic analysis of some essential and fixed oils. Pharmazie 1996, 51, 993-995.

(59) Wang, S. Y.; Chen, P. F.; Chang, S. T. Antifungal activities of essential oils and their constituents from indigenous cinnamon (Cinnamomum osmophloeum) leaves against wood decay fungi. Bioresour. Technol. 2005, 96(7), 813-818.

(60) Delaquis, P.J.; Stanich, K.; Girard, B.; Mazza, G. Antimicrobial activity of individual and mixed fractions of dill, cilantro, coriander and eucalyptus essential oils. Int. J. Food Microbiol. 2002, 74, 101-109.

(61) Fisher, K.; Phillips, C. The effect of lemon, orange and bergamot essential oils and their components on the survival of Campylobacter jejuni, Escherichia coli O157:H7, Listeria monocytogenes, Bacillus cereus and Staphylococcus aureus in vitro and in food systems. J. Appl. Microbiol. 2006, 101, 1232-1240.

(62) Fisher, K.; Phillips, C. Potential antimicrobial uses of essential oils in food: Is citrus the answer? Trends Food Sci Technol. 2008, 19(2), 156-164.

(63) Kordali, S.; Kotan, R.; Mavi, A.; Cakir, A.; Ala, A.; Yildirim, A. Determination of the chemical composition and antioxidant activity of the essential oil of Artemisia dracunculus and of the antifungal and antibacterial activities of Turkish Artemisia absinthium, A. dracunculus, Artemisia santonicum, and Artemisia spicigera essential oils. J. Agric. Food Chem. 2005, 53, 9452-9458.

(64) Hyldgaard, M.; Mygind, T.; Rikke, L.M. Essential oils in food preservation: Mode of action, synergies, and interactions with food matrix components. Front. Microbiol. 2012, 3, 1-24.

(65) Cosentino, S.; Tuberoso, C.I.G.; Pisano, B.; Satta, M.; Mascia,V.; Arzedi, E.; Palmas, F. In vitro antimicrobial activity and chemical composition of Sardinian Thymus essential oils. Lett. Appl. Microbiol. 1999, 29, 130-135.

(66) Bakkali, F.; Averbeck, S.; Averbeck, D.; Idaomar, M. Biological effects of essential oils - a review. Food Chem. Toxicol. 2008, 46, 446-475.

(67) Faleiro, M.L.; Miguel, M.G.; Ladeiro, F.; Venancio, F.; Tavares, R.; Brito, J.C.; Figueiredo, A.C.; Barroso, J.G.; Pedro, L.G. Antimicrobial activity of essential oils isolated from Portuguese endemic species of Thymus. Lett. Appl. Microbiol. 2002, 36, 35-40.

(68) El Asbahani, A.; Miladi, K.; Badri, W.; Sala, M.; Addi, E.H.A.; Casabianca, H.; El Mousadik, A.; Hartmann, D.; Jilale, A.; Renaud, F.N.R.; Elaissari, A. Essential oils: from extraction to encapsulation. Int. J. Pharm. 2015, 483, 220-243.

(69) Sánchez, E.; García, S.; Heredia, N. Extracts of edible and medicinal plants damage membranes of Vibriocholerae. Appl. Environ. Microbiol. 2010, 76, 6888-6894.

(70) Ultee, A.; Bennik, M.H.; Moezelaar, R. The phenolic hydroxyl group of carvacrol is essential for action against the food-borne pathogen Bacillus cereus. Appl. Environ. Microbiol. 2002, 68, 1561-1568.

(71) Mondello, F.; De Bernardis, F.; Girolamo, A.; Cassone, A.; Salvatore, G. In vivo activity of terpinen-4-ol, the main bioactive component of Melaleuca alternifolia Cheel (tea tree) oil against azole-susceptible and-resistant human pathogenic Candida species. BMC Infect. Dis. 2006, 6(1), 158 .

(72) Mekonnen, A.; Yitayew, B.; Tesema, A., Taddese, S. In vitro antimicrobial activity of essential oil of Thymus schimperi, Matricaria Chamomille, Eucalyptus globulus, and Rosmarinus officinalis. Int. J. Microbiol. 2016, 2016, 1-8. 
(73) Prakash, B.; Kujur, A.; Yadav, A.; Kumar, A.; Singh, P. P.; Dubey, N. K. Nanoencapsulation: An efficient technology to boost the antimicrobial potential of plant essential oils in food system. Food Control 2018., 89, 1-11.

(74) Lv, F.; Liang, H.; Yuan, Q.; Li, C. In vitro antimicrobial effects and mechanism of action of selected plant essential oil combinations against four food-related microorganisms. Food Res. Int. 2011, 44, 3057-3064.

(75) Sánchez-González, L.; Vargas, M.; González-Martínez, C.; Chiralt, A.; Cháfer, M. Use of essential oils in bioactive edible coatings: a review. Food Eng. Rev. 2011, 3, 1-16.

(76) Marques, H. M. C. A review on cyclodextrin encapsulation of essential oils and volatiles. Flavour Fragr. J. 2010, 25(5), 313-326.

(77) Donsì, F.; Annunziata M.; Sessa M.; Ferrari G. Nanoencapsulation of essential oils to enhance their antimicrobial activity in foods. LWT-Food Sci. Technol. 2011 44, 1908-1914.

(78) Hosseini, S.F.; Zandi, M.; Rezaei, M.; Farahmandghavi, F. Two-step method for encapsulation of oregano essential oil in chitosan nanoparticles: preparation, characterization and in vitro release study. Carbohyd. Polym. 2013a, 95, 50-56.

(79) Lertsutthiwong, P.; Rojsitthisak, P.; Nimmannit U. Preparation of turmeric oil-loaded chitosan-alginate biopolymeric nanocapsules". Mat. Sci. Eng. C 2009, 29, 856-860.

(80) Wu, Y.; Luo, Y.; Wang, Q. Antioxidant and antimicrobial properties of essential oils encapsulated in zein nanoparticles prepared by liquid-liquid dispersion method. LWT-Food Sci. Technol. 2012, 48(2), 283-290.

(81) Noronha, C.M.; Granada, A.F.; de Carvalho, S.M.; Lino, R.C.; de O.B. Maciel, M.V.; Barreto, P.L.M. Optimization of $\alpha$-tocopherol loaded nanocapsules by the nanoprecipitation method. Ind. Crops Prod. 2013, 50, 896-903.

(82) Almeida, A.P.; Rodríguez-Rojo, S.; Serra, A.T.; Vila-Real, H.; Simplicio, A.L.; Delgadilho, I.; Beirão da Costa, S.; Beirão da Costa, L.; Nogueira, I.D.; Duarte, C.M.M. Microencapsulation of oregano essential oil in starch-based materials using supercritical fluid technology. Innov. Food Sci. Emerg. Technol. 2013, 20, 140-145.

(83) Ayala-Zavala, J.F.; Soto-Valdez, H.; Gónzalez-León, A.; Álvarez-Parrilla, E.; MartínBelloso, O.; González-Aguilar., G.A. Microencapsulation of cinnamon leaf (Cinnamomum zeylanicum) and garlic (Allium sativum) oils in $\beta$-cyclodextrin". J. Incl. Phenom. Macrocycl. Chem. 2008, 60, 359-368.

(84) Toledo Hijo, A.A.C.; Costa, J.M.G.; Silva, E.K.; Azevedo, V.M.; Yoshida, M.I.; Borges, S.V. Physical and thermal properties of oregano (Origanum vulgare L.) essential oil microparticles. J. Food Process Eng. 2015, 38, 1-10.

(85) Beristain, C. I.; Vernon-Carter, E. J. Utilization of mesquite (Prosopis juliflora) gum as emulsion stabilizing agent for spray dried encapsulated orange peel oil. Dry. Technol. 1994, 12, 1727-1733.

(86) Leimann, F.V.; Goncalves, O.H.; Machado, R.A.F.; Bolzan, A. Antimicrobial activity of microencapsulated lemongrass essential oil and the effect of experimental parameters on microcapsules size and morphology. Mat. Sci. Eng. C 2009, 29, 430-436.

(87) Weiss, J.; Gaysinsky, S.; Davidson, M.; McClements, J. Nanostructured encapsulation systems: food antimicrobials. In B.-C. Gustavo, M. Alan, L. David, S. Walter, B. Ken, C. Paul (Eds.), Global Issues in Food Science and Technology 2009,24, 425-479.

(88) Gaysinsky, S.; Taylor, T. T.; Davidson, P. M.; Bruce, B. D.; Weiss, J. Antimicrobial efficacy of eugenol microemulsions in milk against Listeria monocytogenes and Escherichia coli O157:H7. J. Food Prot. 2007, 70, 2631-2637.

(89) Liolios, C.C.; Gortzi, O.; Lalas, S.; Tsaknis, J.; Chinou, I. Liposomal incorporation of carvacrol and thymol isolated from the essential oil of Origanum dictamnus L. and in vitro antimicrobial activity. Food Chem. 2009, 112, 77-83. 
(90) Kfoury, M.; Auezova, L.; Greige-Gerges, H.; Ruellan, S.; Fourmentin, S. Cyclodextrin, an efficient tool for trans-anethole encapsulation: Chromatographic, spectroscopic, thermal and structural studies. Food Chem. 2014, 164, 454-461.

(91) Zhou, Y.; Sun, S.; Bei, W.; Zahi, M. R.; Yuan, Q.; Liang, H. Preparation and antimicrobial activity of oregano essential oil Pickering emulsion stabilized by cellulose nanocrystals. Int. J. Biol. Macromol. 2018, 112, 7-13.

(92) Moghimipour, E.; Ramezani, Z.; Handali, S. Solid lipid nanoparticles as a delivery system for Zataria multiflora essential oil: formulation and characterization. Curr. Drug Deliv. 2013, $10,151-157$.

(93) De Oliveira, E.F.; Paula, H.C.B.; Paula, R.C.M. Alginate/cashew gum nanoparticles for essential oil encapsulation. Colloids Surf. B: Biointerfaces 2014, 113, 146-151.

(94) Maji, T.K.; Baruah, I.; Dube, S.; Hussain, M.R. Microencapsulation of Zanthoxylum limonella oil (ZLO) in glutaraldehyde crosslinked gelatin for mosquito repellent application. Bioresource Technol. 2007, 98, 840-844.

(95) Hsieh, W.; Chang, C.; Gao, Y. Controlled release properties of chitosan encapsulated volatile Citronella oil microcapsules by thermal treatments. Colloids Surf. B 2006, 53, 209214.

(96) Varona, S.; Kareth, S.; Martin, A.; Cocero, M.J. Formulation of lavandin essential oilwith biopolymers by PGSS for application as biocide in ecological agriculture. J. Supercrit. Fluids. 2010, 54, 369-377.

(97) Paula, H.C.B. ; de Oliveira, E.F.; Morais, S.M.; Forte, M.M.C. ; Abreu, F.O.M.S. ; de Paula, R.C.M. ALG/Ca beads as an encapsulation agent of Croton Zehntneri Pax et Hoffm essential oil. Polímeros 2010a, 20, 112-120.

(98) Paula, H.C.B.; Sombra, F.M.; Abreu, F.O.M.S.; de Paula, .R.C.M. Lippia sidoides essen-tial oil encapsulation by angico gum/chitosan nanoparticles, J. Braz. Chem. Soc. 2010b, 21, 2359-2366.

(99) Paula, H.C.B.; Sombra, F.M.; Cavalcante, R.F.; Abreu, F.O.M.S.; de Paula, R.C.M. Preparation and characterization of chitosan/cashew gum beads loaded with Lippia sidoides essential oil. Mat. Sci. Eng. C. 2011, 31, 173-178.

(100) Parris, N.; Cooke, P.H.; Hicks, K.B. Encapsulation of essential oils in zein nanospherical particles. J. Agric. Food Chem. 2005, 53, 4788-4792.

(101) Ponce, A. G.; Roura, S. I.; del Valle, C. E.; Moreira, M. R. Antimicrobial and antioxidant activities of edible coatings enriched with natural plant extracts: in vitro and in vivo studies. Postharvest Biol. Technol. 2008, 49, 294-300.

(102) Liakos, I.; Rizzello, L.; Scurr, D.J.; Pompa, P.P.; Bayer I.S.; Athanassiou, A. All-natural composite wound dressing films of essential oils encapsulated in sodium alginate with antimicrobial properties. Int. J. Pharm. 2014, 463(2), 137-145.

(103) Abreu, F.O.M.S.; Oliveira, E.F.; Paula, H.C.B.; de Paula, R.C.M. Chitosan/cashew gum nanogels for essential oil encapsulation. Carbohydr. Polym. 2012, 89, 1277-1282.

(104) Beyki, M.; Zhaveh, S.; Khalili, S.T.; Rahmani-Cherati, T.; Abollahi, A.; Bayat, M.; Tabatabaei, M.; Mohsenifar, A. Encapsulation of Mentha piperita essentialoils in chitosancinnamic acid nanogel with enhanced antimicrobial activity against Aspergillus flavus. Ind. Crops Prod. 2014, 54, 310-319.

(105) Fernandes, R.V.; Borges, S.V.; Botrel, D.A. Gum arabic/starch/maltodextrin/inulin as wall materials on the microencapsulation of rosemary essential oil. Carbohydr. Polym. 2014, 101, 524-532.

(106) Dima, C.; Cotârlet, M.; Alexe, P.; Dima, S. Microencapsulation of essential oil of pimento [Pimenta dioica (L) Merr.] by chitosan/k-carrageenan complex coacervation method. Innov. Food Sci. Emerg. Technol. 2014, 22, 203-211.

(107) Hosseini, S.M.; Hosseini, H.; Mohammadifar, M.A.; Mortazavian, A.M.; Mohammadi, A.; Khosravi-Darani, K.; Shojaee-Aliabadi, S.; Dehghan, S.; Khaksar, R. Incorporation of 
essential oil in alginate microparticles by multiple emulsion/ionic gelation process. Int. J. Biol. Macromol. 2013b, 62, 582-588.

(108) López, A.; Castro, S.; Andina, M.J.; Ures, X.; Munguía, B.; Llabot, J.M.; Elder, H.; Dellacassa, E.; Palma, S.; Domínguez, L. Insecticidal activity of microencapsulated Schinus molle essential oil. Ind. Crops Prod., 2014, 53, 209-216.

(109) Lv, Y.; Yang, F.; Li, X.; Zhang, X.; Abbas, S. Formation of heatresistant nanocapsules of jasmine essential oil via gelatin/gum arabic based complex coacervation. Food Hydrocoll. 2014, 35, 305-314.

(110) Rodea-González, D.A.; Cruz-Olivares, J.; Román-Guerrero, A.; Rodríguez-Huezo, M.E.; Vernon-Carter, E.J.; Pérez-Alonso, C. Spray-dried encapsulation of chia essential oil (Salvia hispanica L.) in whey protein concentrate-polysaccharide matrices. J. Food Eng. 2012, 111, 102-109.

(111) Banerjee, S.; Chattopadhyay, P.; Ghosh, A.; Goyary, D.; Karmakar, S.; Veer, V. Influence of process variables on essential oil microcapsule properties by carbohydrate polymer-protein blends. Carbohydr. Polym. 2013, 93, 691-697.

(112) Esfandyari-Manesh, M.; Ghaedi, Z.; Asemi, M.; Khanavi, M.; Manayi, A.; Jamalifar, H.; Atyabi, F.; Dinarvand, R. Study of antimicrobial activity of anethole and carvone loaded PLGA nanoparticles. J. Pharm. Res. 2013, 7, 290-295.

(113) Woranuch, S.; Yoksan, R. Eugenol-loaded chitosan nanoparticles: I. Thermal stability improvement of eugenol through encapsulation. Carbohydr. Polym. 2013., 96, 578-585.

(114) Sutaphanit, P.; Chitprasert, P. Optimisation of microencapsulation of holy basil essential oil in gelatin by response surface methodology. Food Chem. 2014, 150, 313-320.

(115) Iannitelli, A.; Grande, R.; Di Stefano, A.; Di Giulio, M.; Sozio, P.; Bessa, L.J.; Laserra, S.; Paolini, C.; Protasi, F.; Cellini, L. Potential antibacterial activity of carvacrolloaded poly (DLlactide-co-glycolide) (PLGA) nanoparticles against microbial biofilm. Int. J. Mol. Sci. 2011, $12,5039-5051$.

(116) Szweda, P.; Gucwa, K.; Kurzyk, E.; Romanowska, E.; Dzierżanowska-Fangrat, K.; Jurek, A. Z.; Kus, P.M.; Milewski, S. Essential oils, silver nanoparticles and propolis as alternative agents against fluconazole resistant Candida albicans, Candida glabrata and Candida krusei clinical isolates. Indian J. Microbiol. 2015, 55(2), 175-183.

(117) Edris, A. E.; Kalemba, D.; Adamiec, J.; Piatkowski, M. Microencapsulation of Nigella sativa oleoresin by spray drying for food and nutraceutical applications. Food Chem. 2016, 204, 326-333.

(118) Ascheri, D.P.R.; Marquez, M.O.M.; Martucci, E.T. Microencapsulation of orange essential oil: Wall material selection. Ciencia Technol. Alime. 2003, 23, 1-6.

(119) Baranauskiene, R.; Venskutonis, P.R.; Dewettinck, K.; Verhe, R. Properties of oregano (Origanum vulgare L.), citronella (Cymbopogon nardus G.) and marjoram (Majorana hortensis L.) flavors encapsulated into milk protein-based matrices. Food Res. Int. 2006, 39 (4), 413-425.

(120) Gascon, A.D.; Zuritz, C.A.; Bustamante, J.A.; Borbon, L.D.; Oberti, G. A study of different formulations of wall support systems for microencapsulation of antioxidant essential oils. WOCMAP Congress of Medicinal and Aromatic Plants, 2001.

(121) Sherry, M.; Charcosset, C.; Fessi, H.; Greige-Gerges, H. Essential oils encapsulated in liposomes: a review. J. Liposome Res. 2013, 232, 268-275.

(122) Zhang, Y.; Niu, Y.; Luo Y.; Ge, M.; Yang, T.; Yu, L.L.; Wang, Q. Fabrication, characterization and antimicrobial activities of thymolloaded zein nanoparticles stabilized by sodium caseinate-chitosan hydrochloride double layers. Food Chem. 2014, 142, 269-275.

(123) Lai, F.; Sinico, C.; de Logu, A.; Zaru, M.; Muller, R.H.; Fadda, A.M.. SLN as a topical delivery system for Artemisia arborescens essential oil: in vitro antiviral activity and skin permeation study. Int. J. Nanomed. 2007, 3, 419-425. 
(124) Waleczek, K. J.; Cabral Marques, H. M.; Hempel, B.; Schmidt, P. C. Phase solubility studies of pure (-)- $\alpha$-bisabolol and camomile essential oil with $\beta$-cyclodextrin. Eur. J. Pharm. Biopharm. 2003, 55 (2), 247-251.

(125) Ciobanu, A.; Mallard, I.; Landy, D.; Brabie, G.; Nistor, D.; Fourmentin, S. Inclusion interactions of cyclodextrins and crosslinked cyclodextrin polymers with linalool and camphor in Lavandula angustifolia essential oil. Carbohydr. Polym. 2012, 87, 3, 1963-1970.

(126) Prata, A. S.; Zanin, M. H. A.; Grosso, I. R. M. Release properties of chemical and enzymatic crosslinked gelatin-gum Arabic microparticles containing a fluorescent probe plus vetiver essential oil. Colloid Surf. B: Biointerfaces 2008, 67(2), 171-178.

(127) Beirao-da-Costa, S.; Duarte, C.; Bourbon A.I.; Pinheiro, A.C.; Januario M.I.N.; Vicente, A.A.; Beirao-da-Costa, M. R.; Delgalillo, I. Inulin potential for encapsulation and controlled delivery of oregano essential oil. Food Hydrocoll. 2013, 33, 199-206.

(128) Shit, S.C.; Shah, P.M. Edible Polymers: Challenges and Opportunities. J. Polym. Sci. 2014, 2014, 1-13.

(129) Martin, A.; Varona, S.; Navarrete, A.; Cocero, M.J. Encapsulation and co-precipitation processes with supercritical fluids: applications with essential oils. Open Chem. Eng. J. 2010, $4,31-41$.

(130) Ribeiro C.; Vicente A. A.; Teixeira J.A.; Miranda C. Optimization of edible coating composition to retard strawberry fruit senescence. Postharvest Biol. Technol. 2007, 44, (1), 63-70.

(131) Dutta, P.K.; Tripathi, S.; Mehrotra, G.K.; Dutta, J. Perspectives for chitosan based antimicrobial films in food applications. Food Chem. 2009, 114, 1173-1182.

(132) Campos, C.; Gerschenson, L.; Flores, S. Development of edible films and coatings with antimicrobial activity. Food Bioproc. Tech. 2011, 4(6), 849-875.

(133) Espitia, P.J.P.; Du, W.-X.; Avena-Bustillos, R.d.J.; Soares, N.d.F.F.; McHugh, T.H. Edible films from pectin: Physical-mechanical and antimicrobial properties-A review. Food Hydrocoll. 2014, 35, 287-296.

(134) Maftoonazad, N.; Ramaswamy, H. S.; Moalemiyan, M.; Kushalappa, A. C. Effect of pectinbased edible emulsion coating on changes in quality of avocado exposed to Lasiodiplodia theobromae infection. Carbohydr. Polym. 2007, 68, 341-349.

(135) Shrestha, A. K.; Arcot, J.; Paterson, J. L. Edible coating materials - their properties and use in the fortification of rice with folic acid. Food Res. Int . 2003, 36(9-10), 921-928.

(136) Debeaufort, F.; Quezada-Gallo, J.-A.; Voilley, A. Edible films and coatings: tomorrow's packagings: a review. Crit. Rev. Food Sci. Nutr. 1998, 38, 299-313.

(137) Arguello-Garcia, E.; Solorza-Feria, J.; Rendon-Villalobos, J. R.; Rodriguez-Gonzalez, F.; Jimenez-Perez, A.; Flores-Huicochea, E. Properties of edible films based on oxidized starch and zein. Int. J. Polym. Sci. 2014, 2014, 1-10.

(138) Cho, S. Y.; Rhee, C. Sorption characteristics of soy protein films and their relation to mechanical properties. LWT-Food Sci. Technol. 2002, 35, 151-157.

(139) Seydim, A. C.; Sarikus, G. Antimicrobial activity of whey protein based edible films incorporated with oregano, rosemary and garlic essential oils. Food Res. Int. 2006, 39(5), 639644.

(140) Sobral, P. J. A.; Menegalli, F. C.; Hubinger, M. D.; Roques, M. A. Mechanical, water vapor barrier and thermal properties of gelatin based edible films. Food Hydrocoll. 2001, 15(6), 423 432.

(141) Mojumdar, S.; Moresoli, C.; Simon, L.; Legge, R.. Edible wheat gluten (WG) protein films. J. Therm. Anal. Calorim. 2011, 104, 929-936.

(142) Chiumarelli, M.; Hubinger, M. D. 2012. Stability, solubility, mechanical and barrier properties of cassava starch - carnauba wax edible coatings to preserve fresh-cut apples. Food Hydrocoll., 28, 59-67. 
(143) Morillon, V. Debeaufort, F., Blond G., Capella, M., Voilley, A. Factors affecting the moisture permeability of lipid based edible films: A review. Crit. Rev. Food Sci. Nutr. 2002, 42, 67-89.

(144) Chen, C. H.; Kuo, W. S.; Lai, L. S. Effect of surfactants on water barrier and physical properties of tapioca starch/decolorized hsian-tsao leaf gum films. Food Hydrocoll. 2009, 23(3), 714-721

(145) Lima, A. M.; Cerqueira, M. A.; Souza, B. W. S.; Santos, E. C. M.; Teixeira, J. A.; Moreira, R. A.; Vincente, A.A. New edible coatings composed of galactomannans and collagen blends to improve the postharvest quality of fruits e Influence on fruits gas transfer rate. J. Food Eng. 2010, 97, 101-109.

(146) Bravin, B.; Peressini, D.; Sensidoni, A. Development and application of polysaccharidelipid edible coating to extend shelflife of dry bakery products. J. Food Eng. 2006, 76(3), 280 290.

(147) Cao, N.; Fua, Y.; He, Y. Preparation and physical properties of soy protein isolate and gelatin composite films. LWT-Food Sci. Technol. 2007, 35, 680-686.

(148) Tharanathan, R.N. Biodegradable films and composite coatings: past, present and future. Trends Food Sci. Technol. 2003, 14, 71-78.

(149) Bazana, M. T.; Codevilla, C. F.; de Menezes, C. R. Nanoencapsulation of Bioactive Compounds: Challenges and Perspectives. Curr. Opin Food Scie. 2019,26, 47-56.

(150) Amenta, V.; Aschberger, K.; Arena, M.; Bouwmeester, H.; Moniz, F.B.; Brandhoff, P.; Gottardo, S; Marvin, H.J.P.; Mech, A.; Quirós Pesudo, L.; Rauscher, H.; Schoonjans, R.; Vettori, M.V.; Weigel, S.; Peters, R.J. Regulatory aspects of nanotechnology in the agri/feed/food sector in EU and non-EU countries. Regul. Toxicol. Pharmacol. 2015, 73(1), 463-476. https://doi.org/10.1016/j.tifs.2016.06.008.

(151) Donsì, F.; Marchese, E.; Maresca, P.; Pataro, G., Vu, K. D.; Salmieri, S.; Lacroix, M.; Ferrari, G. Green beans preservation by combination of a modified chitosan based-coating containing nanoemulsion of mandarin essential oil with high pressure or pulsed light processing. Postharvest Biol. Technol. 2015, 106, 21-32.

(152) Espina, L.; Somolinos, M.; Lorán, S.; Conchello, P.; García, D.; Pagán, R. Chemical composition of commercial citrus fruit essential oils and evaluation of their antimicrobial activity acting alone or in combined processes. Food Control. 2011, 22 (6), 896-902.

(153) Zambrano-Zaragoza, M. L.; González-Reza, R.; Mendoza-Muñoz, N.; Miranda-Linares, V.; Bernal-Couoh, T. F.; Mendoza-Elvira, S.; Quintanar-Guerrero, D. Nanosystems in Edible Coatings: A Novel Strategy for Food Preservation. Int. J. Molec. Sci. 2018, 19 (3), 705.

(154) Aloui, H.; Khwaldia, K. Natural antimicrobial edible coatings for microbial safety and food quality enhancement. Compr. Rev. Food Sci. Food Saf. 2016, 15 (6), 1080-1103.

(155) Maisanaba, S.; Llana-Ruiz-Cabello, M.; Gutiérrez-Praena, D.; Pichardo, S.; Puerto, M.; Prieto, A.; Jos, A.; Cameán, A. New advances in active packaging incorporated with essential oils or their main components for food preservation. Food Rev. Int. 2017, 33 (5), 447-515.

(156) Yang, H.; Wang, J.; Yang, F.; Chen, M.; Zhou, D.; Li, L. Active packaging films from ethylene vinyl alcohol copolymer and clove essential oil as shelf life extenders for grass carp slice. Packag. Technol. Sci. 2016, 29(7), 383-396.

(157) Ray, S.; Jin, T.; Fan, X.; Liu, L.; Yam, K. L. Development of chlorine dioxide releasing film and its application in decontaminating fresh produce. J. Food Sci. 2013, 78, 276-284.

(158) Pola, C.C.; Medeiros, E. A. A.; Pereira, O. L.; Souza, V.G.L.; Otoni, C.G.; Camilloto, G.P.; Soares, N.F.F. Cellulose acetate active films incorporated with oregano (Origanum vulgare) essential oil and organophilic montmorillonite clay control the growth of phytopathogenic fungi. Food Packaging and Shelf Life, 2016, 9, 69-78. 


\section{SUPPORTING INFORMATION}

Table 1. Classes of food preservatives and their potential toxic effect on human health. $a=$ antimicrobials; $b=$ Antioxidants; *GRAS substances.

\section{PRESERVATIVES FOOD USE TOXIC EFFECTS}

REFERENCES

\begin{tabular}{lll}
\hline $\begin{array}{l}\text { Propionic acid, } \\
\text { Na, Ca and K salts }\end{array}$ & $\begin{array}{l}\text { To prevent mould } \\
\text { and fungal } \\
\text { contamination }\end{array}$ & $\begin{array}{l}\text { Reduction of the immune } \\
\text { system activity and possible } \\
\text { occurrence of allergic } \\
\text { diseases. }\end{array}$ \\
Inhibitors of acid, & $\begin{array}{l}\text { Genotoxic activity } \\
\text { gould and yeast } \\
\text { growth. }\end{array}$ \\
Acetic acid & Antimicrobials & $\begin{array}{l}\text { Genotoxic and mutagenic } \\
\text { agent for human lymphocytes. } \\
\text { Corrosive; it produces vapors } \\
\text { which are irritant for the eyes } \\
\text { and the respiratory system. }\end{array}$ \\
antimicrobials & $\begin{array}{l}\text { Reduction of the immune } \\
\text { system activity and possible } \\
\text { occurrence of allergic } \\
\text { diseases. }\end{array}$
\end{tabular}

$\mathrm{Na}$ and $\mathrm{K}$ salts

Genotoxic in human (17)

${ }^{a}$ p-Hydroxybenzoate Me,

Antimicrobials

lymphocytes (in vitro).

Slight estrogenic activity.

Et, Pr, Bu esters*

For curing and Methemoglobinaemia

Nitrate, $\mathrm{Na}$ and $\mathrm{K}$ salts preserving meat and fish

Carcinogenesis (at high doses).

Sulphites

Antimicrobic in Genotoxic

Sulphur dioxide food and beverage

${ }^{\mathrm{b}}$ Ascorbic acid

DNA damage

Antioxidant

$\mathrm{Na}$ and $\mathrm{Ca}$ salts and antibrowning

Palmitate*

Isoascorbic acid

Antioxidant

Na salt and antibrowning

BHA

Antioxidant

Genotoxicity

hydroxyanisole)

BHT (butylated

Antioxidant

Genotoxicity

hydroxytoluene)

Carcinogenicity dodecyl)

bter/-Butylhydroquinone

Antioxidant

DNA damage

(TBHQ) 
EDTA (ethylenediamine Metal chelating tetraacetic acid, and $\mathrm{Ca}$ agents and $\mathrm{Na}$ salts) ${ }^{*}$

${ }^{\mathrm{b}}$ Citric acid

Metal chelating Chromosomal aberrations agents

Gingival cell death

Table 2. Essential oils with different antimicrobial activity.

\begin{tabular}{|c|c|c|c|}
\hline $\begin{array}{l}\text { Plant from } \\
\text { which EO is } \\
\text { extracted }\end{array}$ & Species of bacteria & EOs or components & References \\
\hline \multirow{5}{*}{$\begin{array}{l}\text { Cymbopogon } \\
\text { spp. }\end{array}$} & Bacillus ceretis Bacillus subtilis & & (43) \\
\hline & $\begin{array}{l}\text { Escherichia coli Pseudomonas } \\
\text { aeruginosa Salmonella enteritidis } \\
\text { Staphylococcus auerus }\end{array}$ & & (44) \\
\hline & & Neral & $(45)$ \\
\hline & $\begin{array}{l}\text { Fusarium proliferatum Fusarium } \\
\text { graminearum }\end{array}$ & Geranial & $(46)$ \\
\hline & $\begin{array}{l}\text { Salmonella typhimurium and } \\
\text { Staphylococcus aureus }\end{array}$ & & \\
\hline \multirow{9}{*}{$\begin{array}{l}\text { Rosmarinus } \\
\text { officinalis L. }\end{array}$} & Escherichia coli & Camphor/1,8- & $(47)$ \\
\hline & Staphylococcus aureus & cineole/borneol & \\
\hline & $V$. parahaemolyticus & & \\
\hline & Aeromonas hydrophila & & \\
\hline & Listeria monocytogenes & & \\
\hline & Pseudomonas fluorescens & & \\
\hline & Salmonella enteritidi & & \\
\hline & $\begin{array}{l}\text { Staphylococcus aureus, Bacillus } \\
\text { subtilis, }\end{array}$ & $\begin{array}{l}\alpha \text {-pinene, } \quad \beta \text {-pinene, } \\
\text { myrcene } \quad 1,8 \text {-cineole, }\end{array}$ & $(48)$ \\
\hline & $\begin{array}{l}\text { Escherichia } \\
\text { pneumoniae }\end{array}$ & $\begin{array}{l}\text { borneol, camphor, and } \\
\text { verbenone }\end{array}$ & \\
\hline \multirow[t]{9}{*}{ Origanum spp. } & Fusarium proliferatum & Neral & $(45)$ \\
\hline & Fusarium graminearum & Geranial & (46) \\
\hline & $\begin{array}{l}\text { Salmonella Typhimurium, } \\
\text { Y. enterocolitica, }\end{array}$ & & (49) \\
\hline & Escherichia coli & Carvacrol & \\
\hline & Staphylococcus aureus, & Eugenol & \\
\hline & Lactobacillus plantarum & & \\
\hline & $\begin{array}{l}\text { Aspergillus niger, Geotrichum and } \\
\text { Rhodotorula }\end{array}$ & & \\
\hline & Listeria monocytogenes & Thymol & $(50)$ \\
\hline & Staphylococcus aureus & Carvacrol & \\
\hline
\end{tabular}


Thymus vulgaris Salmonella typhimurium

L.

Staphylococcus aureus

Syzygium aromaticum

L.

Listeria monocytogenes

Escherichia coli

Fusarium proliferatum graminearum

Pseudomonas fluorescens

S. typhimurium

Thymus vulgaris Listeria monocytogenes

L.

Escherichia coli

Salmonella typhimurium

Staphylococcus aureus

Curcuma longa Bacillus cereus

L.

Lippia

chevalieri

and

Lippia

multiflora

Ocimum Staphylococcus aureus,

basilicum L. Yersinia enterocolitica,

Aspergillus niger

Rhodotorula

Lactobacillus plantarum,

Listeria monocytogenes,

Staphulococcus aureus

Escherichia coli,

Pseudomonas aeruginos

Salmonella typhimurium Yersinia enterocolitica,

Rhodotorula

Staphylococcus aureus

Escheriachia coli

Aspergillus niger

Cinnamomum Coriolus versicolor

osmophloeum

Lenzites betulina

Fusarium
Carvacrol

Eugenol

Carvacrol, thymol, y- (53)

terpinene, $\mathrm{p}$-Cymene

Eugenol

Thymol

Cinnamaldehyde

Turmerone

p-Cymene

Thymol

2-Phenyl

propionate

ethyl

Linalool

Linalool

coccineus

Oligoporus lowei

Antrodia taxa

Fomitopsis pinicola Laetiporus

Linalool

Trans-cinnamaldehyde 


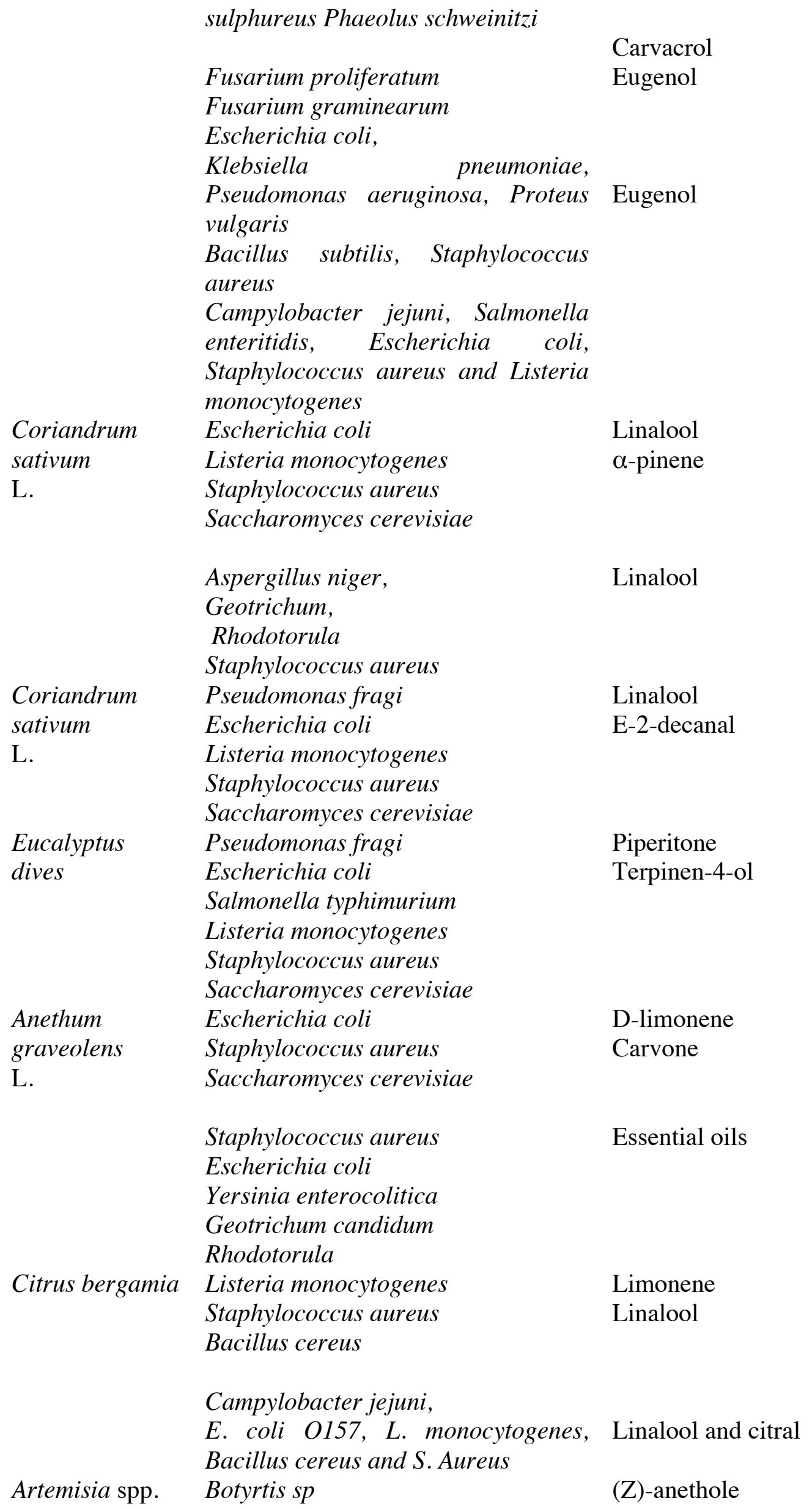




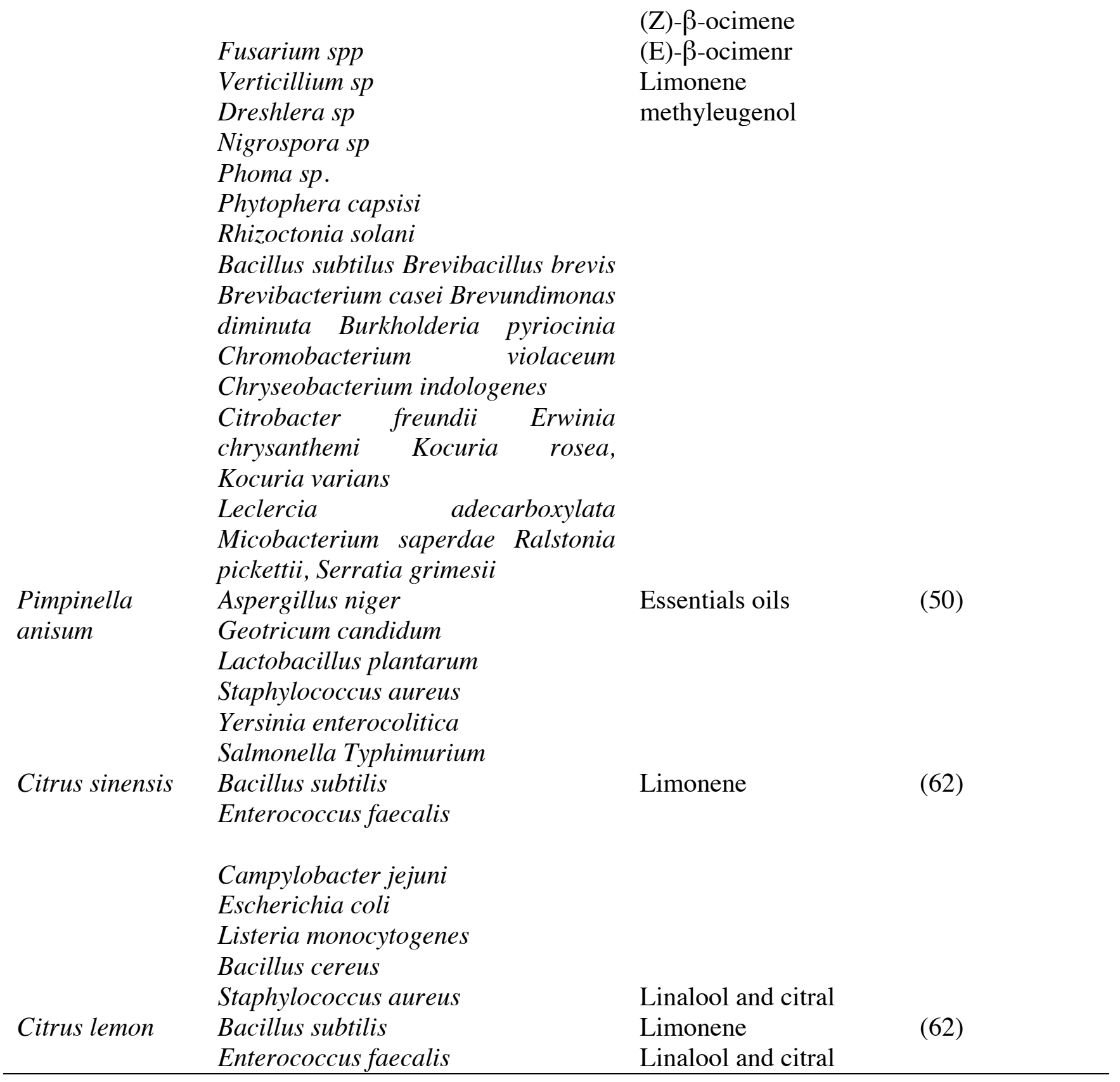

Table 3. Particles loaded with essential oils with antimicrobial activity on food products.

\begin{tabular}{|c|c|c|c|}
\hline $\begin{array}{l}\text { Pharmaceutical } \\
\text { Form }\end{array}$ & EOs or components & Methods & References \\
\hline Nanoparticles & Oregano & Ionic gelation & (78) \\
\hline \multirow[t]{2}{*}{ Nanocapsules } & $\begin{array}{l}\text { Turmeric oil } \\
\text { thymol carvacrol }\end{array}$ & $\begin{array}{l}\text { Gelation } \\
\text { Liquid-liquid dispersion }\end{array}$ & $\begin{array}{l}(79) \\
(80)\end{array}$ \\
\hline & $\alpha$-tochopherol & Nanoprecipitation & $(81)$ \\
\hline
\end{tabular}




\begin{tabular}{|c|c|c|c|}
\hline \multirow[t]{2}{*}{ Microparticles } & Oregano & $\begin{array}{l}\text { Supercritical fluid } \\
\text { Technology }\end{array}$ & $(82)$ \\
\hline & Cinnamon leaf and garlic oils & $\begin{array}{l}\text { Molecular-complex with } \beta \text { - } \\
\text { cyclodextrin }\end{array}$ & $(83)$ \\
\hline \multirow[t]{3}{*}{ Microcaspules } & Oregano & Spray-drying & (84) \\
\hline & Orange essential oil & Spray-drying & $(85)$ \\
\hline & Lemongrass & Coacervation & $(86)$ \\
\hline \multirow[t]{3}{*}{ Nanoemulsion } & $\begin{array}{l}\text { Terpenes mixture of Melaleuca } \\
\text { alternifolia and D-limonene }\end{array}$ & & (77) \\
\hline & & High $\quad$ Pressure & \\
\hline & Eugenol & Homogenization (HPH) & (87) \\
\hline \multirow[t]{2}{*}{ Microemulsion } & $\begin{array}{l}\text { Eugenol } \\
\text { Carvacrol }\end{array}$ & $\begin{array}{l}\text { Mix of lipophilic phase and } \\
\text { surfactants }\end{array}$ & (87) \\
\hline & Eugenol & $\begin{array}{l}\text { Mix of lipophilic phase and } \\
\text { surfactants }\end{array}$ & (88) \\
\hline Liposomes & $\begin{array}{l}\text { Carvacrol and } \\
\text { Thymol }\end{array}$ & Thin film hydration & (89) \\
\hline
\end{tabular}

Table 4: Particles loaded with essential oil (adapted from El Asbahani et al. ${ }^{68}$ ). 


\begin{tabular}{|c|c|c|c|c|c|c|c|c|c|}
\hline $\begin{array}{l}\text { Essentials } \\
\text { oils/EOs } \\
\text { compound }\end{array}$ & Polymer & $\begin{array}{l}\text { Pharmaceutical } \\
\text { Form }\end{array}$ & $\begin{array}{l}\text { Solvent/non- } \\
\text { solvent }\end{array}$ & $\begin{array}{l}\text { Stabilizer } \\
\text { agent }\end{array}$ & Application & $\begin{array}{l}\text { Size } \\
(\mathbf{n m})\end{array}$ & $\begin{array}{l}\text { Zeta } \\
\text { Potential } \\
\quad(\mathrm{mV}) \\
\end{array}$ & Method & References \\
\hline Lippia sidoides & $\begin{array}{l}\text { Alginate/cashe } \\
\text { w gum }\end{array}$ & Nanoparticles & Water & Tween 80 & Larvicide & $\begin{array}{l}223- \\
399 \\
\text { nm }\end{array}$ & $-30 /-36$ & Spray-drying & (93) \\
\hline $\begin{array}{l}\text { Zanthoxylum } \\
\text { limonella }\end{array}$ & Gelatin & Microparticles & $\begin{array}{l}\text { Water/glutaral- } \\
\text { dehyde solution }\end{array}$ & $\begin{array}{l}\text { Tween } 80, \\
\text { glutaralde } \\
\text { hyde } \\
\text { solution }\end{array}$ & $\begin{array}{l}\text { Mosquito } \\
\text { repellent }\end{array}$ & - & - & Coacervation & (94) \\
\hline Citronella oil & Chitosan & Microparticles & - & $\begin{array}{l}\text { Natural } \\
\text { coconut } \\
\text { oil }\end{array}$ & $\begin{array}{l}\text { Mood lifting, } \\
\text { depression, } \\
\text { restless } \\
\text { reducing, } \\
\text { deodorizing, } \\
\text { sterilizing, bug } \\
\text { repelling } \\
\text { properties }\end{array}$ & $\begin{array}{l}11- \\
225 \\
\mathrm{~m} \mu\end{array}$ & - & $\begin{array}{l}\text { Modified } \\
\text { orifice method }\end{array}$ & (95) \\
\hline $\begin{array}{l}\text { Lavandin } \\
\text { essential oil }\end{array}$ & $\begin{array}{l}\text { PEG } \\
\text { n-octenyl } \\
\text { succinic } \\
\text { (OSA)- } \\
\text { modified } \\
\text { starches }\end{array}$ & Microcapsules & Water & $\begin{array}{l}\text { (OSA)- } \\
\text { modified } \\
\text { starches }\end{array}$ & $\begin{array}{l}\text { Natural } \\
\text { biocides }\end{array}$ & $\begin{array}{l}30- \\
100 \\
\mathrm{~m} \mu\end{array}$ & - & $\begin{array}{l}\text { PGSS } \\
\text { PGSS-drying }\end{array}$ & (96) \\
\hline $\begin{array}{l}\text { Croton } \\
\text { zehntneri Pax } \\
\text { et Hoffm }\end{array}$ & $\begin{array}{l}\text { Alginate/ } \\
\text { cashew gum }\end{array}$ & $\begin{array}{l}\text { Beads (spherical } \\
\text { particles) }\end{array}$ & Water & Tween 80 & Larvicide & $\begin{array}{l}0,71- \\
1,46 \\
\mathrm{~mm}\end{array}$ & - & $\begin{array}{l}\text { Emulsion } \\
\text { preparation }\end{array}$ & (97) \\
\hline Lippia sidoides & $\begin{array}{l}\text { Chitosan/angic } \\
\text { o gum }\end{array}$ & Nanoparticles & $\begin{array}{l}\text { Acetic } \\
\text { acid/water }\end{array}$ & Tween80 & Larvicide & $\begin{array}{l}18.7- \\
271 \\
\mathrm{~nm}\end{array}$ & $-21 /-14.7$ & - & (98) \\
\hline Lippia sidoides & $\begin{array}{l}\text { Chitosan/cashe } \\
\text { w gum }\end{array}$ & Beads & $\begin{array}{l}\text { Acetic } \\
\text { acid/water }\end{array}$ & Tween 80 & Larvicide & $\begin{array}{l}1.27 \pm \\
0.2 \\
\mathrm{~nm}\end{array}$ & - & $\begin{array}{l}\text { Emulsion } \\
\text { preparation }\end{array}$ & (99) \\
\hline
\end{tabular}




\begin{tabular}{|c|c|c|c|c|c|c|c|c|}
\hline $\begin{array}{ll}\text { Oregano, } & \text { red } \\
\text { thyme, } & \text { and } \\
\text { cassia } & \end{array}$ & Zein & Nanospeheres & Water/ethanol & - & $\begin{array}{l}\text { Feed } \\
\text { applications }\end{array}$ & $\begin{array}{l}25- \\
250 \\
\mathrm{~nm}\end{array}$ & - & $\begin{array}{l}\text { Phase } \\
\text { separation }\end{array}$ \\
\hline $\begin{array}{l}\text { Oregano and } \\
\text { thyme oil }\end{array}$ & Zein & Nanoparticles & Water/ethanol & - & $\begin{array}{l}\text { Antimicrobials } \\
\text { / } \\
\text { antioxidant }\end{array}$ & $\begin{array}{l}51.9- \\
328.1\end{array}$ & - & $\begin{array}{l}\text { Liquid-liquid } \\
\text { dispersion } \\
\text { method }\end{array}$ \\
\hline Tea tree & Lecithin & Nanoemulsion & $\begin{array}{l}\text { Sunflower and } \\
\text { palm oil/water }\end{array}$ & $\begin{array}{l}\text { Tween 20, } \\
\text { glycerol } \\
\text { monooleat } \\
\text { e, soy } \\
\text { lecithin, } \\
\text { Cleargum }\end{array}$ & Antimicrobial & $\begin{array}{l}74.4- \\
365.7 \\
\mathrm{~nm}\end{array}$ & - & $\begin{array}{l}\text { High Pressur } \\
\text { Homogenizati } \\
\mathrm{n}\end{array}$ \\
\hline $\begin{array}{l}\text { Cinnamon and } \\
\text { thyme essential } \\
\text { oils }\end{array}$ & $\beta$-cyclodextrin & $\begin{array}{l}\text { Inclusion } \\
\text { complexes }\end{array}$ & Water & - & - & - & - & $\begin{array}{l}\text { Co- } \\
\text { precipitation }\end{array}$ \\
\hline $\begin{array}{l}\text { Elicriso italic, } \\
\text { chamomile } \\
\text { blue, cannella } \\
\text { corteccia } \\
\text { (cinnamon), } \\
\text { levanda vera } \\
\text { (lavender), tea } \\
\text { tree, } \\
\text { peppermint, } \\
\text { eucalyptus } \\
\text { globulus } \\
\text { juvenile, } \\
\text { lemongrass } \\
\text { and lemon } \\
\text { essential oils }\end{array}$ & $\begin{array}{l}\text { Sodium } \\
\text { alginate }\end{array}$ & Films & Water & Igepal & $\begin{array}{l}\text { Anti-microbial } \\
\text { and anti-fungal } \\
\text { properties } \\
\text { (wound } \\
\text { dressings but } \\
\text { also in food } \\
\text { packaging, } \\
\text { medical device } \\
\text { protection and } \\
\text { disinfection, } \\
\text { and indoor air } \\
\text { quality } \\
\text { improvement } \\
\text { materials,) }\end{array}$ & - & - & - \\
\hline Lippia sidoides & $\begin{array}{l}\text { Chitosan } \\
\text { cashew gum }\end{array}$ & / Nanoparticles & $\begin{array}{l}\text { Acetic acid } \\
\text { solution/water }\end{array}$ & Tween 80 & Larvicide & $\begin{array}{l}335- \\
558 \mathrm{n} \\
\mathrm{m}\end{array}$ & $4-49.6$ & $\begin{array}{l}\text { Complex } \\
\text { coacervation }\end{array}$ \\
\hline
\end{tabular}




\begin{tabular}{|c|c|c|c|c|c|c|c|c|c|}
\hline $\begin{array}{l}\text { Origanum } \\
\text { vulgare }\end{array}$ & Starch & Microparticles & Carbon dioxide & - & $\begin{array}{l}\text { Food } \\
\text { preservative }\end{array}$ & $\begin{array}{l}<10 \mu \\
\mathrm{m}\end{array}$ & - & $\begin{array}{l}\text { Supercritical } \\
\text { fluid } \\
\text { technology }\end{array}$ & (82) \\
\hline $\begin{array}{l}\text { Mentha } \\
\text { piperita }\end{array}$ & $\begin{array}{l}\text { Chitosan and } \\
\text { cinnamic acid }\end{array}$ & Nanoparticles & $\begin{array}{l}\text { Acetic } \\
\text { acid/water }\end{array}$ & Tween 80 & Antimicrobial & $\begin{array}{l}<100 \\
\mathrm{~nm}\end{array}$ & - & Ionic gelation & (104) \\
\hline $\begin{array}{l}\text { Rosemary } \\
\text { essential oil }\end{array}$ & $\begin{array}{l}\text { Gum Arabic, } \\
\text { maltodextrin } \\
\text { and } \\
\text { modified } \\
\text { starch }\end{array}$ & Microparticles & Water & - & - & $\begin{array}{l}12.1- \\
13.5 \mu \\
\mathrm{m}\end{array}$ & - & Spray drying & (105) \\
\hline Pimenta dioica & $\begin{array}{l}\text { Chitosan and } \\
\text { k-carrageenan }\end{array}$ & Microparticles & $\begin{array}{l}\text { Acetic } \\
\text { acid/water }\end{array}$ & Tween 40 & $\begin{array}{l}\text { Antioxidant } \\
\text { and } \\
\text { antimicrobial } \\
\text { in food } \\
\text { industry }\end{array}$ & $\begin{array}{l}1172- \\
1224 \mu \\
\mathrm{m}\end{array}$ & - & $\begin{array}{l}\text { Complex } \\
\text { coacervation }\end{array}$ & (106) \\
\hline Oregano & Chitosan & nanoparticles & $\begin{array}{l}\text { Acetic } \\
\text { acid/water }\end{array}$ & Tween80 & Antimicrobial & $\begin{array}{l}281.5- \\
402.2\end{array}$ & - & Ionic gelation & $(78)$ \\
\hline $\begin{array}{l}\text { Satureja } \\
\text { hortensis }\end{array}$ & Alginate & Microparticles & Water & $\begin{array}{l}\text { Tween } 80 \text {, } \\
\text { Span } 80\end{array}$ & Antibacterial & $\begin{array}{l}47- \\
117 \mu \\
\mathrm{m}\end{array}$ & - & Ionic gelation & (107) \\
\hline Schinus molle & $\begin{array}{l}\text { Maltodextrin } \\
\text { and gum } \\
\text { Arabic }\end{array}$ & Microparticles & Water & - & Insecticidal & $\begin{array}{l}0.2- \\
40 \mu \mathrm{m}\end{array}$ & - & Spray drying & (108) \\
\hline Jasmine & $\begin{array}{l}\text { Gelatin and } \\
\text { gum Arabic }\end{array}$ & Nanoparticles & Water & - & - & $\begin{array}{l}74- \\
384 n \\
m\end{array}$ & $\begin{array}{l}-8.67 / \\
-1.92\end{array}$ & $\begin{array}{l}\text { Complex } \\
\text { coacervation }\end{array}$ & (109) \\
\hline $\begin{array}{l}\text { Salvia } \\
\text { hispanica }\end{array}$ & $\begin{array}{l}\text { Whey protein } \\
\text { concentrate } \\
\text { and } \\
\text { gum Arabic or } \\
\text { whey protein } \\
\text { concentrate } \\
\text { and mesquite }\end{array}$ & Microparticles & Water & $\begin{array}{l}\text { Mesquite } \\
\text { gum and } \\
\text { arabic } \\
\text { gum }\end{array}$ & - & $\begin{array}{l}13.17 \\
- \\
28.20 \\
\mu \mathrm{m}\end{array}$ & - & Spray drying & (110) \\
\hline
\end{tabular}




\begin{tabular}{|c|c|c|c|c|c|c|c|c|c|}
\hline $\begin{array}{l}\text { Zanthoxylum } \\
\text { limonella }\end{array}$ & $\begin{array}{l}\text { gum } \\
\text { Alginate } \\
\text { gelatine }\end{array}$ & Microparticles & $\begin{array}{l}\text { Water/ } \\
\text { methylene } \\
\text { chloride }\end{array}$ & Tween 80 & $\begin{array}{l}\text { Mosquito } \\
\text { repellent }\end{array}$ & $\begin{array}{l}209.4 \\
1- \\
223.1 \\
7 \mu \mathrm{m}\end{array}$ & - & $\begin{array}{l}\text { Emulsion } \\
\text { solvent } \\
\text { evaporation }\end{array}$ & (111) \\
\hline $\begin{array}{l}\text { Carvone and } \\
\text { anethole }\end{array}$ & $\begin{array}{l}\text { Poly(lactide- } \\
\text { co-glycolide) }\end{array}$ & nanoparticles & $\begin{array}{l}\text { Dichloromethan } \\
\text { e-acetone/ } \\
\text { aqueous } \\
\text { polyvinyl } \\
\text { alcohol solution }\end{array}$ & & Antimicrobial & $\begin{array}{l}112- \\
472 \\
\mathrm{~nm}\end{array}$ & - & $\begin{array}{l}\text { Emulsion } \\
\text { solvent } \\
\text { evaporation, } \\
\text { Nanoprecipitat } \\
\text { ion }\end{array}$ & (112) \\
\hline Eugenol & Chitosan & Nanoparticles & $\begin{array}{l}\text { DMSO/water } \\
\text { Acetone/water }\end{array}$ & Tween 60 & $\begin{array}{l}\text { Antioxidant } \\
\text { for thermal } \\
\text { processing }\end{array}$ & $\begin{array}{l}80- \\
100 \\
\mathrm{~nm}\end{array}$ & $16.2-33.5$ & Ionic gelation & (113) \\
\hline $\begin{array}{l}\text { Ocimum } \\
\text { sanctum Linn } \\
\text { essential oil }\end{array}$ & Gelatin & Microparticles & Water & Tween 80 & $\begin{array}{l}\text { Natural } \\
\text { antioxidant }\end{array}$ & $\begin{array}{l}392.3 \\
0 \\
\mu \mathrm{m}\end{array}$ & - & $\begin{array}{l}\text { Simple } \\
\text { coacervation }\end{array}$ & (114) \\
\hline $\begin{array}{l}\text { Carvacrol and } \\
\text { thymol }\end{array}$ & $\begin{array}{l}\text { Egg L- } \alpha- \\
\text { phosphatidylch } \\
\text { oline } \\
\text { and cholesterol }\end{array}$ & Liposomes & $\begin{array}{l}\text { Chloroform- } \\
\text { methanol/Water }\end{array}$ & - & Antimicrobial & - & - & Film hydration & (89) \\
\hline Carvacrol & PLGA & Nanoparticles & Acetone/ & $\begin{array}{l}\text { Tween } \\
\text { 80/Pluroni } \\
\text { c F68 }\end{array}$ & $\begin{array}{l}\text { Antimicrobial } \\
\text { biofilm }\end{array}$ & $\begin{array}{l}209.8 \\
\mathrm{~nm}\end{array}$ & -18.99 & $\begin{array}{l}\text { Nanoprecipitat } \\
\text { ion }\end{array}$ & (115) \\
\hline Lemon & $\begin{array}{l}\text { Silver- } \\
\text { modified } \\
\text { titanium } \\
\text { dioxide }\end{array}$ & Nanonoparticles & $\begin{array}{l}\text { Water/AOT/cy- } \\
\text { clohexane }\end{array}$ & - & Antifungal & $\begin{array}{l}5-10 \\
\mathrm{~nm}\end{array}$ & - & $\begin{array}{l}\text { Microemulsion } \\
\text { system }\end{array}$ & (116) \\
\hline Nigella sativa & $\begin{array}{l}\text { Gum } \\
\text { Arabic/maltod } \\
\text { extrin }\end{array}$ & & Water & Tween 80 & $\begin{array}{l}\text { Fortification of } \\
\text { processed food } \\
\text { and } \\
\text { nutraceuticals. }\end{array}$ & $\begin{array}{l}2.33 \\
\mu \mathrm{m}\end{array}$ & - & Spray drying & (117) \\
\hline & & & & 32 & & & & & \\
\hline
\end{tabular}




\begin{tabular}{|c|c|c|c|c|c|c|c|c|c|}
\hline $\begin{array}{l}\text { Orange } \\
\text { essential oil }\end{array}$ & $\begin{array}{l}\text { Gum } \\
\text { Arabic/maltod } \\
\text { extrin }\end{array}$ & Microparticles & Water & - & - & - & - & Spray drying & (118) \\
\hline $\begin{array}{l}\text { Origanum } \\
\text { vulgare L., } \\
\text { Cymbopogon } \\
\text { nardus G., } \\
\text { Majorana } \\
\text { hortensis L. }\end{array}$ & $\begin{array}{l}\text { Skimmed milk } \\
\text { powder (SMP) } \\
\text { Whey protein } \\
\text { concentrate } \\
\text { (WPC) }\end{array}$ & Microparticles & Water & - & Antimicrobial & $\begin{array}{l}6-280 \\
\mu \mathrm{m} \\
2-556 \\
\mu \mathrm{m}\end{array}$ & - & Spray-drying & (119) \\
\hline $\begin{array}{l}\text { Rosmarinus } \\
\text { officinalis, } \\
\text { Larrea sp., } \\
\text { Acantholippia } \\
\text { seriphioides, } \\
\text { Origanum } \\
\text { vulgare, } \\
\text { Artemisia sp., } \\
\text { Lavandula sp., } \\
\text { Eucalyptus sp. }\end{array}$ & $\begin{array}{l}\text { Arabic gum; } \\
\text { Maltodextrin, } \\
\text { and Cellulose } \\
\text { microcrystallin } \\
\text { e }\end{array}$ & Microparticles & Water & - & Antioxidant & - & - & Spray-drying & (120) \\
\hline $\begin{array}{l}\text { Anethum } \\
\text { graveolens, } \\
\text { Artemisia } \\
\text { arborescens } \\
\text { L., Eugenia } \\
\text { uniflora L., } \\
\text { Santolina } \\
\text { insularis, Tea } \\
\text { tree, } \\
\text { Zanthoxylum } \\
\text { tingoassuiba }\end{array}$ & $\begin{array}{l}\text { Egg yolk } \\
\text { phosphatidylch } \\
\text { oline, } \\
\text { dimiristroylph } \\
\text { osp-hatidyl } \\
\text { choline, } \\
\text { Cholesterol }\end{array}$ & Liposomes & - & - & Antimicrobial & $\begin{array}{l}232- \\
360 \\
\mathrm{~nm}\end{array}$ & - & $\begin{array}{l}\text { Thin film } \\
\text { hydration }\end{array}$ & (121) \\
\hline
\end{tabular}


camaldulensis

Eucalyptus

camaldulensis

$l$

Atractylodes

macrocephala,

Rose

Thymol

Zein

Nanoparticles

Water-ethanol

Compritol 888 Solid Lipid -

Artemisia

arborescens

ATO

Nanoparticles

\section{Camomile}

trans-

Cinnamaldehy

de, eugenol, cinnamon

bark, and

clove bud

extracts

Lavandula $\quad \beta$-cyclodextrin -

angustifolia
Modified

rapid

expansion of

supercritical

solution

of

of

solution 


\begin{tabular}{|c|c|c|c|c|c|c|c|c|c|}
\hline Vetiver & $\begin{array}{l}\text { Gelatin-gum } \\
\text { Arabic }\end{array}$ & Microparticles & & Tween 80 & - & $\begin{array}{l}20-60 \\
\mu \mathrm{m}\end{array}$ & - & $\begin{array}{l}\text { Complex } \\
\text { coacervation }\end{array}$ & (126) \\
\hline $\begin{array}{l}\text { Oregano } \\
\text { essential oil }\end{array}$ & Inulin & Microparticles & Water & - & - & $\begin{array}{l}34.5 \\
\mu \mathrm{m}\end{array}$ & - & Spray drying & (127) \\
\hline
\end{tabular}


Table 5. Edible polymers used in food field with their main characteristics. ${ }^{148,128}$

\begin{tabular}{llll}
\hline $\begin{array}{l}\text { Polymer } \\
\text { category }\end{array}$ & Edible polymers & Characteristic & References
\end{tabular}

$\begin{array}{ll}\text { Hydrocolloids } & \text { Starch } \\ & \text { Chitosan }\end{array}$

Carrageenan

Alginate

Pectin

Gums

Casein

Cellulose

Polypeptides Collagen

Zein

Soy proteins

Milk proteins

Gelatin

Wheat gluten

Lipids Wax

Fatty acid

Surfactants

Composite Galactomannans

Edible Polymer and collagen

Starch

Methylcellulose

Soybean oil

Soy protein

and gelatin
Hydrophilic, poor water vapor

$(130,131,132)$

and gas barrier properties $\left(\mathrm{O}_{2}\right.$,

$\left.\mathrm{CO}_{2}\right) ;$ good mechanical properties.

Predominantly hydrophilic, (136) good oxygen barriers, poor moisture-barrier

Hydrophobic, water vapor and gas barrier. Often used in association with others.

Combination of the functional characteristics of the different polymers 